\title{
MANAJEMEN SUMBER DAYA MANUSIA BERBASIS KOMPETENSI SEKOLAH DASAR ISLAM DI TULUNGAGUNG
}

\author{
Retno Indayati \\ retnoindayati@yahoo.com \\ IAIN Tulungagung
}

\begin{abstract}
Islamic elementary school is a based Islamic elementary education institution that gives students basic competencies to continue their study to the more higher level. Recently the society's trust toward the school is getting increase. One of the factors affecting the increase of the society's interest toward the Islamic elementary school is the quality of the teachers who have integrity, comitment and competencies. This research was intended to analyze and find out: 1) planning of Competence Based Human Resource Management in Islamic Elementary School; 2) developing strategies of Competence Based Human Resource Management in Islamic Elementary School; and 3) the effects of developing Competence Based Human Resource Management in Islamic Elementary School. This study used a qualitative approach by with multi-case study using multisite research design. The data were collected using in-depth interview, participant observation, and documentation. The results of this research revealed that: 1) planning of Human Resource in Islamic Elementary School is religious-based competency approach. The steps are: a) need analysis, b) the determination of the standard qualification of teachers (academic, religious, experience, motivation and 'dakwah"); c) selection, with open system selection, d) apprenticeship and evaluation, include: competence, motivation and commitment of devotion. 2) Developing strategies of Competence Based Human Resource Management in Islamic Elementary School by synergizing the continuous training and development (CTD), performance evaluation and build a spirit of integration 'dakwah' and education. Goal of human resources development in the aspects of: a) improving the commitment and internship through giving compensation, career development, personal and family guidance, and building good cooperation; b) improving academic and spiritual competence through training and socialization, supervisison, further studies, motivation that working is religious good deeds, praying together, and getting close to Allah (al qiyadah); 3) the effects of developing human resource were teachers have high motivation, they became models for the students, they are loyal and committed to serve and give attention to the students. From the findings above it can be concluded that the human resource management at Islamic elementary school is spirituality based human resource management.
\end{abstract}

Key Words: Human Resource Management, based competence, Islamic Elementary School.

\section{Abstrak}

Sekolah Dasar Islam merupakan lembaga pendidikan dasar berbasis Islam yang memberikan kemampuan dasar kepada siswa untuk mengikuti jenjang pindidikan lebih lanjut. Kepercayaan masyarakat terhadap SD Islam, akhir-akhir ini semakin meningkat. Salah satu faktor yang mempengaruhi meningkatnya minat masyarakat terhadap SD Islam adalah kualitas SDM pendidiknya yang memiliki integritas, komitmen dan kompetensi keilmuannya. Penelitian ini bertujuan untuk menganalisis dan menemukan: 1) perencanaan SDM berbasis kompetensi di SD Islam; 2) strategi pengembangan SDM berbasis kompetensi di SD Islam; dan 3) dampak pengembangan SDM di SD Islam. Penelitian ini menggunakan pendekatan kualitatif, jenis studi kasus, dan menggunakan rancangan penelitian multisitus. Pengumpulan data menggunakan wawancara mendalam, observasi partisipan dan dokumentasi. Hasil penelitian menunjukkan bahwa: 1) perencanaan SDM guru di SD Islam menggunakan pendekatan kompetensi berbasis religius. Langkahnya: a) analisis kebutuhan, b) penentuan standar kualifikasi pendidik (akademis, religius, 
pengalaman, motivasi dan dakwah), c) seleksi, dengan open system selection, d) magang dan evaluasi, meliputi: kompetensi, motivasi dan komitmen pengabdian. 2) Strategi pengembangan SDM berbasis kompetensi di SD Islam dengan mensinergikan continous training and development (CTD), evaluasi kinerja dan membangun semangat integrasi dakwah dan pendidikan. Sasaran pengembangan SDM pada aspek: a) komitmen dan pengabdian, melalui; pemberian kompensasi, pengembangan karir, pembinaan pribadi dan keluarga, dan silaturahmi; b) peningkatan kemampuan akademik dan spiritual melalui pelatihan dan sosialisasi, supervisi, studi lanjut, motivasi bekerja adalah ibadah, doa bersama, mendekatkan diri kepada Allah (al qiyadah); 3) dampak pengembangan SDM guru di SD Islam, guru memiliki motivasi kerja tinggi, mampu menjadi teladan bagi siswa, memiliki loyalitas tinggi dan memiliki komitmen terhadap perhatian dan pelayanan terbaik kepada siswa. Dari hasil penelitian tersebut maka dapat ditarik kesimpulan bahwa manajemen SDM di SD Islam adalah berbasis spiritual (spirituality based human resource management).

Kata Kunci: manajemen sumber daya manusia, berbasis kompetensi, sekolah dasar Islam.

\section{Pendahuluan}

Pendidikan

bermutu membutuhkan guru yang kompeten dan profesional serta bersedia mengajar dengan hati yang ikhlas, dilandasi dengan nilai Islam. Guru sebagai sosok yang kaya akan ilmu pengetahuan dan mengamalkannya, bekerja demi menolong orang lain, dan memberi petunjuk yang dapat bermanfaat bagi orang lain. Peran guru sebagai bagian dari usaha bersama dalam membangun jati diri bangsa harus terus dijaga keberlanjutannya (sustainable). Jati diri bangsa untuk masa depan Indonesia, diyakini dapat dibangun dari pendidikan, menuju bangsa dan negara yang maju dan terpadang (Malik Fadjar, 2005: 101-103). Pendidikan merupakan wilayah strategis yang diyakini dapat membangun bangsa menuju bangsa yang bermartabat. Upaya untuk mewujudkan cita-cita tersebut, diperlukan adanya pandangan masyarakat yang mampu mengarahkan menjadi bangsa yang bermartabat. Oleh karena itu pengembangan kualitas manusia harus menjadi paradigma pembangunan (Rasiyo, 2005: 14).

Pembangunan dengan paradigma pengembangan kualitas sumber daya manusia, pendidikan hendaknya diposisikan sebagai pondasi utama. Guru menempati posisi penting untuk mewujudkan sumber daya manusia yang berkualitas. Pola pendidikan apa pun eksistensi guru tetap penting, guru merupakan unsur dasar pendidikan yang berpengaruh terhadap penciptaan SDM berkualitas (Malik Fadjar, 2005: 188). Sumber Daya Manusia yang unggul merupakan tujuan pembangunan itu sendiri. Pembangunan menjadi bermakna apabila dapat menciptakan kebahagiaan (Nurcholish Madjid, 2003: 14). Kebahagiaan hidup dalam bekerja sebagai pengalaman batin dapat dicapai melalui pendidikan. Sumber daya manusia, dalam hal ini guru berperan besar dalam meningkatkan kualitas kebahagiaan dengan kualitas kerja dan produktivitas.

Tugas guru untuk mengajar dan mendidik merupakan tugas dan tanggung jawab guru sebagai tenaga profesional. Tugas seorang guru dapat dilaksanakan dengan optimal apabila guru yang memiliki kompetensi yang tinggi, yang bekerja dengan ikhlas, selalu berusaha menyempurnakan, meningkatkan, mensucikan dan membimbing hati para murid mendekatkan diri kepada Allah SWT (Imam Syafi'ie, 1992: 23).. Oleh sebab itu, mutu pendidikan di suatu sekolah sangat ditentukan oleh kompetensi yang dimiliki para guru dalam menjalankan tugasnya. Apalagi guru di tingkat sekolah dasar, merupakan faktor penting dalam pendidikan untuk mengajarkan ilmunya, dan tidak akan ada proses pengajaran tanpa adanya guru.

$$
\text { Kompetensi pada dasarnya }
$$
merupakan kemampuan yang diperoleh dari hasil belajar, yang dapat ditunjukkan dalam melakukan pekerjaan sehari-hari, dapat melaksanakan tugas sesuai dengan proses atau standar yang ditentukan, dapat melakukan pekerjaan pada tingkat yang 
memuaskan. Di dalamnya mengandung kompetensi kognisi, kompetensi konasi, dan kompetensi afeksi yang dikembangkan berdasarkan nilai-nilai hidup yang mulia. Guru sebagai Sumber Daya Manusia di lembaga pendidikan Islam tingkat Sekolah Dasar, merupakan pribadi yang memiliki identitas dan kompetensi, komitmen pada kualitas pekerjaannya, berjiwa penuh pengabdian, berkekuatan problem solving dengan berupaya meningkatkan dan menyesuaikan kompetensi akademik, serta kedalaman spiritual dengan meneladani Rasul SAW.

Manajemen SDM memiliki tujuan tertentu yang berorientasi pada optimalisasi sistem kerja dalam lembaga pendidikan. Hal ini bertujuan untuk mendayagunakan guru secara efektif dan efisien guna mencapai hasil yang optimal, namun dalam kondisi yang menyenangkan (Mulyasa, 2003: 152). Tujuan tersebut mengupayakan adanya keseimbangan antara proses mengajar dengan situasi kerja. Pendayagunaan tenaga guru secara efektif dan efisien merupakan pemanfaatan tenaga guru sehingga mereka bisa mengajar secara maksimal dan produktif, sekaligus menekan pemborosan. Pendayagunaan ini tidak bersifat pemaksaan fisik, tetapi pendayagunaan ini bersifat strategi kerja yang tetap mempertimbangkan unsur-unsur manusiawi. Hal ini karena para guru adalah manusia yang tidak bisa disamakan dengan mesin, sehingga mereka membutuhkan interaksi sosial yang sehat, serta sentuhan rohani yang menentramkan, bahkan suasana yang menentramkan akan mampu mengurangi perasaan stres dan beban kerja berat yang muncul dalam menjalani tugas sehari-hari.

SD Islam Al Azhaar dan SD Islam Al Munawwar Tulungagung, juga berperan di dalam membangun para guru bagi masyarakat Tulungagung khususnya, dan bagi bangsa Indonesia pada umumnya. Berbagai langkah dalam mengelola SDM di SD Islam Al Azhaar dan di SD Islam Al Munawwar dilakukan melalui perencanaan SDM dan pengembangan SDM. Perencanaan SDM dan pengembangan SDM ini dilakukan dengan menekankan pada kompetensi yang harus dimiliki oleh guru di lmbaga pendidikan Islam. Berdasarkan uraian di atas, maka dipandang tepat untuk dilakukan penelitian dengan judul Manajemen SDM Sekolah Dasar Islam berbasis kompetensi di SD Islam Al Azhaar dan SD Islam Al Munawwar. Hal ini juga didasari beberapa pertimbangan antara lain manajemen SDM SD Islam berbasis kompetensi sangat penting dilakukan untuk meningkatkan kualitas pendidikan yang bermuara pada kualitas guru. Hal tersebut berimbas pada kualitas proses dan hasil pendidikan para murid, apalagi di tengah-tengah adanya program sertifikasi guru. Hasil penelitian ini juga diharapkan dapat memberikan sumbangan bagi lembaga pendidikan Islam, utamanya di tingkat pendidikan dasar dalam melakukan manajemen SDM SD Islam berbasis kompetensi.

Fokus dalam penelitian ini adalah manajemen pengembangan guru berbasis kompetensi. Adapun pertanyaan penelitian adalah: (1) perencanaan SDM berbasis kompetensi di SD Islam Al Azhaar dan SD Islam Al Munawwar Tulungagung; (2) strategi pengembangan SDM berbasis kompetensi di SD Islam Al Azhaar dan SD Islam Al Munawwar Tulungagung; dan (3) pengembangan SDM di SD Islam Al Azhaar dan SD Islam Al Munawwar Tulungagung.

\section{Perencanaan Sumber Daya Manusia}

Pengadaan tenaga kerja perlu dilandasi pemikiran bahwa "none of us is as smart as all of us." (Warren Bennis and Patricia Ward Biederman, 1997: 1v). Pekerjaan yang besar akan menghasilkan karya yang besar dan menakjubkan jika dilakukan dalam suasana kebersamaan. Semangat kerja sama didasarkan pada upaya untuk memberi kesempatan kepada sesama tenaga kerja, ataupun tenaga kerja baru. Menghidupkan nuansa "welcome" bagi tenaga pendidik yang sangat peduli terhadap permasalahan pendidikan Islam, dan khususnya di tingkat SD Islam.

Dalam Al Qur'an surat Al Mujadalah ayat 11, Allah berfirman bahwa setiap orang beriman diperintahkan untukmemberikan kelapangan bagi orang lain. Hal ini memberi pemahaman untuk 
bersemangat membangun peluang bekerja sama, memberi kelapangan kepada sesama muslim dalam pergaulan dan usaha mencari kebajikan dan kebaikan, berusaha menyenangkan hati saudara-saudara sesama muslim, memberi pertolongan dan sebagainya termasuk hal yang dianjurkan Rasul".

Ada tiga langkah dalam pengadaan tenaga kerja yang efektif, yaitu perencanaan SDM, rekrutmen, dan seleksi. Dalam konteks tingkat kehidupan apapun, seseorang baik secara pribadi maupun secara kelompok, mereka selalu berinteraksi dengan orang lain. Setiap kali berhadapan dengan sesama tentu ada gagasan atau masalah yang dihadapi, dan disitulah terjadi interaksi untuk mengambil keputusan. Perencanaan SDM yang baik mencerminkan kematangan sebuah lembaga dalam mempertimbangkan perencanaan berdasarkan pada kemampuannya. Maksud dan tujuan lembaga tersebut terkait dengan operasional jangka pendek dan jangka panjang. Perencanaan SDM yang luas dan luwes, dengan antisipasi perkiraan kemungkinan kondisi dan kejadian-kejadian di dunia pendidikan masa depan inilah yang menjadi peran manajemen SDM di lembaga pendidikan. Hal ini dilakukan bersama dengan rencana untuk memenuhi persyaratan jangka pendek sampai dengan jangka panjang melalui pemanfaatan SDM, pengembangan SDM, pekerjaan dan rekrutmen, penggunaan sistem informasi (Tb. Sjafri Mangkuprawiro, 2004: 71). Jikalau semua ini mendapatkan perhatian yang cukup, maka sebagai tenaga kerja yang memiliki kekuatan spiritual serta kepribadian yang aktif, akan dapat menjadi kekuatan yang dapat menggerakkan perjuangan lembaga pendidikan Islam.

\section{Strategi Pengembangan Sumber Daya Manusia}

Manajemen SDM yang efektif akan menjamin pertumbuhan lembaga, serta memperlancar kinerja. Manajemen SDM yang efektif, akan berimplikasi pada kinerja organisasi, termasuk meningkatnya produktivitas pegawai dan menguatnya kinerja keuangan. Memiliki kemampuan untuk menarik dan mempertahankan SDM yang berkualitas tinggi sebagai senjata strategis keberlangsungan organisasi termasuk lembaga pendidikan Islam. Adapun strategi dalam pengembangan SDM dilakukan melalui membangun tenaga guru yang kompeten dan mempertahankan tenaga guru yang efektif. Strareginya adalah (1) membangun Tenaga Guru yang Kompeten; (2) guru yang efektif.

Dampak pengembangan SDM terhadap kepribadian guru dapat diuraikan berikut ini. (1) Loyalitas. Aspekaspek loyalitas kerja yang lain terdapat pada individu dikemukakan oleh Siswanto, yang menitik beratkan pada pelaksanaan kerja yang dilakukan karyawan antara lain: 1) taat pada peraturan; 2) tanggung jawab; 3) sikap kerja; dan 4) tingginya perhatian guru terhadap murid (Wasty Sumanto, 1984: 124). (2) Peningkatan motivasi dan keteladanan.Motivasi berasal dari bahasa Latin, Mavere yang berarti dorongan atau daya penggerak. Motivasi ini hanya diberikan kepada manusia, khususnya kepada para bawahan atau pengikut (Malayu S.P Hasibuan, 2009: 216). Motivasi mempersoalkan bagaimana caranya mendorong gairah kerja bawahan, agar mereka mau bekerja keras dengan memberikan semua kemampuan dan keterampilannya untuk mewujudkan tujuan lembaga. Motivasi (to motivate) berarti tindakan dari seseorang yang ingin mempengaruhi orang lain untuk berperilaku (to behave) secara tertentu (M. Karebet Widjajakusuma, 2003: 168).

Al-Quran memberikan penekanan utama bagaimana motivasi terhadap pekerjaan dan menerangkan dengan jelas bahwa manusia diciptakan di bumi untuk bekerja keras untuk mencari penghidupan masing-masing. Sebagaimana firman Allah SWT dalam surat al-Jumu'ah ayat 10 , yang artinya: "Apabila telah ditunaikan shalat, Maka bertebaranlah kamu di muka bumi; dan carilah karunia Allah dan ingatlah Allah banyak-banyak supaya kamu beruntung".

Berdasarkan ayat tersebut bahwa motivasi yang tersirat, yaitu berupa keinginan yang memenuhi kebutuhan 
dengan cara mencari karunia Allah SWT. Mencari karunia Allah tidaklah dengan berdiam diri, tetapi dengan berusaha dan bekerja untuk memenuhi kebutuhan hidup kita, sehingga terjadi keseimbangan dalam hidup kita untuk kehidupan di dunia dan akhirat. Gambaran hidup yang bahagia di surga merupakan peringatan kepada manusia bahwa kesenangan dan kegembiraan di dunia bergantung pada usahanya. Kehidupan yang bahagia dijamin untuk mereka yang bekerja dan tidak membuang waktu dengan berdiam diri saja.

\section{Manajemen Sumber Daya Manusia Berbasis Kompetensi dalam Perspektif Islam}

Manajemen Sumber Daya Manusia yang efektif memiliki peran penting untuk keberlangsungan dan kesuksesan organisasi (Laurie J. Mullins, 2002:4). Manusia merupakan sumber daya utama dalam organisasi. Semakin meningkatnya kehidupan global dan lingkungan yang kompetitif, peran manajemen dalam organisasi memiliki kontribusi dominan. Organisasi akan baik, apabila para manajer dan anggota yang ada didalamnya juga baik.

Manajemen SDM dalam presfektif Islam, apalagi di Lembaga Pendidikan Islam perlu memperhatikan kualitas individu, person yang ada didalamnya, yang mendukung lajunya organisasi tersebut. Terutama peran leader yang terintegrasi dengan manajer, atau sebagai manajer yang menguasai peran sebagai leader. Siagaan dalam Raharjo menyebutkan bahwa "kepemimpinan merupakan inti manajemen karena ia sebagai motor penggerak bagi sumber daya manusia dan lainnya". Sedangkan Ralp M. Stogdill menjelaskan bahwa kepemimpinan adalah suatu proses mempengaruhi aktivitas kelompok dalam upaya perumusan dan pencapaian tujuan (Muhamad Muiz Raharjo, 2011:44).

Demikian pula halnya, kecerdasan jiwa yang akan mempengaruhi tingkat akademik tenaga guru harus menjadi perhatian untuk diberdayakan. Dengan memahami tentang modal dasar manusia menjadi cerdas yaitu apabila peralatan dasar yang dianugerahkan Allah SWT kepada setiap calon anak manusia sejak dalam kandungan berupa pendengaran, dan akal pikiran sebagaimana tertulis dalam Firman Allah SWT dalam surat Assajadah ayat 9 yang artinya: "Kemudian dia menyempurnakan dan meniupkan ke dalamnya roh (ciptaan)-Nya dan dia menjadikan bagi kamu pendengaran, penglihatan dan hati; (tetapi) kamu sedikit sekali bersyukur" (QS As-Sajdah: 9)

Dengan mensyukuri nikmat karunia Allah SWT yang tak terhingga nilainya, maka disela-sela kegiatan guru dalam menunaikan kewajibannya. Demikian pula dalam halnya pengembangan spiritualitas tenaga guru yang diyakini akan berpengaruh besar terhadap tataran berfikir, berkemauan, dan berperasaan yang berujung pada kualitas ibadah mereka. Lembaga senantiasa memfasilitasi berkembangnya karakter yang berdasarkan Akhlak Islam, sebagaimana yang diajarkan Al-Ghazali dalam Said Hawwa bahwa menjadi muslim yang berkarakter tentu memperhatikan penyakit hati yang harus dihindari antara lain: 1) penyakit kafir, munafiq, fasiq dan bid'ah bangunan keimanan yang suci; 2) penyakit cinta kedudukan dan jabatan; 3) penyakit ujub, sombong dan pelit, apalagi menyembunyikan ilmu pengetahuan; 4) penyakit cinta dunia dan mengikuti hawa nafsu (Said Hawwa, 2006:54).

\section{Pendekatan dan Rancangan Penelitian}

Peneitian ini jenis penelitian lapangan (field research) studi kasus. Studi kasus ini digunakan untuk mengungkkan kasus yang terjadi di SD Islam Azhaar dan SD Islam Al Munawwar Tulungagung mengenai manajemen SDM berbasis kompetensi. Dalam penelitian ini, desain yang digunakan adalah multisitus (multisitus), yakni di SDI Al Azhaar, dan SDI Al Munawwar. Hal ini didasarkan pada pendapat Bogdan dan Biklen yang mengatakan, jika peneliti mengkaji dua atau lebih subyek latar, atau tempat penyimpanan data, maka yang dikerjakan tersebut adalah penelitian multisitus (Bogdan dan Biklen, 1998:123). Hal-hal 
yang menjadi karakteristik pada setiap lokasi penelitian adalah sebagai berikut: 1) secara organisasi, SD Islam Al Azhaar dan SD Islam Al Munawwar merupakan lembaga yang dikelola oleh Yayasan bersama lembaga yang lain, yaitu PAUD, SMP dan SMA; 2) sistem pembelajaran, kedua lembaga menerapkan sistem fullday school; dan 3) Geografis, kedua lembaga berada di lokasi yang dekat dengan pusat kota.

Penelitian kualitatif ini merupakan instrumen utama dan merupakan suatu keharusan kehadirannya di lokasi. Dalam penelitian kualitatif peneliti sendiri atau dengan bantuan orang lain merupakan alat pengumpul data utama. Metode pengumpulan data meliputi wawancara, observasi, dan dokumentasi. Analisis data situs individu selama di lapangan menurut Miles dan Huberman dalam Sugiyono (2000: 91), berlangsung terus menerus sampai tuntas dengan aktivitasnya yaitu data reduction, data display, dan data conclusion drawing/verivication).

\section{Perencanaan SDM Berbasis Kompetensi}

Analisis kebutuhan guru meliputi: kualifikasi pendidikan standar minimal pendidikan S1 sesuai dengan kebutuhan lowongan guru, mampu membaca $\mathrm{Al}$ Quran, dan memiliki pengalaman baik akademik maupun non akademik. Langkah selanjutnya rekrutmen guru, meliputi tahap magang dan interview prestasi. Tahap magang dilakukan bagi calon guru yang lulus seleksi selama 3 bulan, 8 bulan dan 1 tahun. Interview prestasi merupakan tahapan bagi calon guru yang telah lulus pada tahapan magang, dengan wawancara terhadap calon guru yang bersangkutan, orang tua santri, komite sekolah dan teman sejawat guru lainnya. Apabila memuaskan maka calon guru tersebut dapat diterima menjadi guru di LPI Al Azhaar. Seleksi penerimaan guru-guru di LPI Al Azhaar dilaksanakan secara terbuka. Fenomena ini menambah trust masyarakat bahwa LPI mempelopori sebuah perubahan yang mendasar anti KKN yang menjadi sumber kemerosotan kualitas SDM pendidikan. Temuan penelitian mengenai perencanaan SDM berbasis kompetensi di SD Islam Al Azhaar sebagaimana dalam gambar berikut ini:

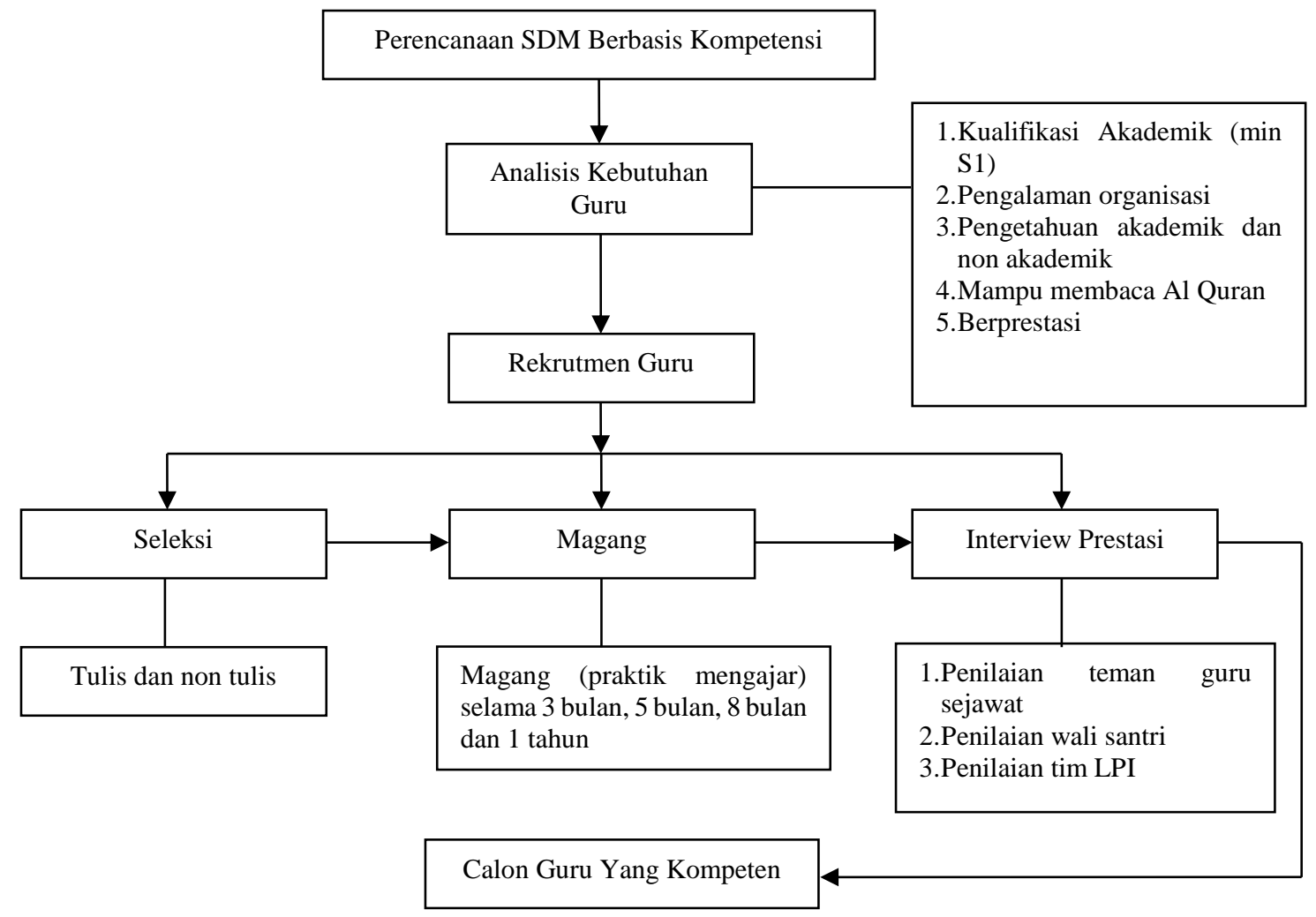




\section{Strategi Pengembangan SDM Guru Berbasis Kompetensi}

Proses magang yang harus dilalui oleh calon guru di SD Islam Al Azhaar merupakan usaha pelatihan untuk meninmgkatkan komitmen terhadap lembaga. Komitmen untuk berjuang dengan ikhlas ditingkatkan dengan model magang kepada guru-guru senior. Strategi pengembangan SDM berbasis kompetensi di SD Islam Al Azhaar dilakukan melalui pengembangan: 1) komitmen dan pengabdian guru; dan 2) kemampuan akademik dan spiritualitas guru.

$$
\text { Strategi pengembangan }
$$

kemampuan komitmen dan pengabdian guru dilakukan dengan cara: 1) memberikan motivasi kepada guru bahwa mengajar diniatkan karena Allah dan mengajar untuk masa depan bangsa Indonesia dan Islam; 2) pembinaan guru (bina usroh); dan 3) memberikan kompensasi kepada guru, yang berupa kenaikan pangkat, pemberian gaji/sertifikasi dan bisyaroh.

Pembinaan guru juga dilakukan melalui bina usroh. Setiap hari Ahad dilaksanakan pertemuan dengan seluruh pengelola, guru dan karyawan. Pembinaan keruhanian setiap hari jum'at juga menjadi upaya mengingatkan semangat berkorban dalam membina generasi Robbani. Setiap bulan dilaksanakan bina keluarga sakinah yang disebut dengan bina usroh. Materi pembinaan tentang aqidah Islamiyah. Pada hari jum'at dilaksanakan pembinaan tutorial tentang berbagai problematikan pengajaran di kelas. Bahasa Arab, Aqidah, Al Qur'an. Agar tidak terjadi kejenuhan juga dilaksanakan tukar pendapat tentang pengalaman dalam mangatasi kendalakendala proses interaksi edukatif. Kata kunci dari pertemuan rutin setiap jum'at, sabtu, dan ahad ini dimaksudkan dalam rangka memupuk suasana keakraban dan suasana dakwah Islamiyah. Kompensasi yang diberikan kepada guru berupa kenaikan tunjangan/gaji, atau promosi di jabatan yang lebih tinggi. Kenaikan gaji serta tunjangan bagi guru ini disesuaikan dengan masa pengabdian serta dedikasi mereka. Selain itu juga berupa bisyaroh yang merupakan tambahan insentif berupa beras, uang bensin/transport dengan mempertimbangkan jarak tempuh dari rumah ke sekolah, baju seragam, sarapan pagi, makan siang, snack dan minuman. Selain itu juga berupa sertifikasi, yang mana para guru yang memiliki masa pengabdian tinggi (guru senior).

Pelatihan dan workshop yang diikuti guru di SD Islam Al Azhaar tidak hanya lokal, tetapi juga nasional. SDI Al Azhaar juga aktif dalam persatuan di Jaringan Sekolah Islam Terpadu (JSIT). Selanjutnya hasil pelatihan dan workshop, diadakan sosialisasi bagu guru yang lain. Sosialisasi dilakukan secara formal dan non formal.

Kegiatan do'a yang disebut dengan dzikrul jama'i yang khas LPI Al Azhaar, "Allohuma yan robbana, cukupana, luberono, beras akeh, duwit akeh, kanggo ngaji lunga kaji barokahe nabi wali." $\mathrm{Al}$ Qiyadah adalah pilar kepemimpinan sesuai surat An Nisa' ayat 59. Intinya melatih kepemimpinan atas dasar ketaatan kepada Alloh SWT dan Rosul. Pemimpin al Azahaar dipilih orang yang paling taat kepada Alloh dan RasulNya. Achievemen Motivation Trainning (AMT) didasarkan pada hadits bahwa khoirun nas anfauhum linnas. Pekerjaan para nabi dan rosul itu adalah mendidik/guru.

Strategi pengembangan SDM berbasis kompetensi dapat dicermati berikut ini. Pertama, komitmen dan pengabdian yaitu (1) motivasi: mengajar karena Allah dan untuk masa depan umat dan bangsa; (2) pembinaan guru melalui bina usroh; dan (3)memberikan kompensasi: pangkatm gaji, bisyaroh, sertifikasi. Kedua, peningkatan kemampuan akademik dan spiritual adalah (1) peningkatan jenjang pendidikan guru; (2) pelatihan dan workshop bagi guru (local \& nasional); (3) sosialisasi hasil pelatihan bagi guru lain; (4) keteladanan (kepemimpinan) bagi guru; (5) ceramah agama rutin; (6) kegiatan Doa (dzikrul jama'i); (7) Al Qiyadah dan AMT (Achievment Motivation Training); dan (8) dan guru sebagai murabbi. 


\section{Dampak Pengembangan SDM Guru Berbasis Kompetensi}

Dampak nyata dari pengembangan SDM guru di SD Islam Al Azhaar meliputi: 1) adanya motivasi dan keteladanan guru; 2) adanya loyalitas guru; dan 3) tingginya perhatian guru terhadap siswa. Dampak dari pengembangan SDM guru yakni motivasi guru dalam mengajar, mendidik di Al Azhaar didasarikan pada semangat berjuang dalam ruhul jihad yang tinggi. Loyalitas guru yang terjaga karena setiap jum'at, sabtu,dan ahad dilaksanakan upaya menjaga ukuwah Islamiyah dalam dakwah Islam. Kompetensi guru selalu direview setiap hari sabtu dengan cara diseminasi teori-teori paedagogik. Saling tukar pengalaman dalam mengatasi permasalahan pengajaran di kelas. Temuan penelitian mengenai fokus dampak pengembangan SDM berbasis kompetensi di SD Islam Al Azhaar dapat dilihat dalam gambar di bawah.

Dari temuan penelitian dari masing-masing fokus penelitian di SD Islam Al Azhaar maka dapat diperoleh temuan penelitian mengenai manajemen SDM berbasis kompetensi di SD Islam Al Azhaar, sebagai berikut:
Perencanaan SDM guru berbasis kompetensi dilakukan dengan 1) analisis kebutuhan guru (need analysis); dan rekrutmen guru, rekrutmen guru dilakukan dengan tahap magang dan interview prestasi. Tahap perencanaan SDM berbasis kompetensi ini memperhatikan kompetensi yang diperlukan meliputi lualifikasi akademik (minimal S1), mampu membaca Al Quran dengan baik, memiliki pengalaman organisasi, memiliki kemampuan akademik dan non akademik yang baik dan memiliki prestasi.

Strategi pengembangan kemampuan komitmen dan pengabdian guru dilakukan dengan cara: 1) memberikan motivasi kepada guru bahwa mengajar diniatkan karena Allah dan mengajar untuk masa depan bangsa Indonesia dan Islam; 2) pembinaan guru (bina usroh); dan 3) memberikan kompensasi kepada guru, yang berupa kenaikan pangkat, pemberian gaji/sertifikasi dan bisyaroh. Sedangkan strategi pengembangan kemampuan akademik dan spiritual dilakukan dengan cara: 1) peningkatan jenjang pendidikan atau studi lanjut; 2) pelatihan dan

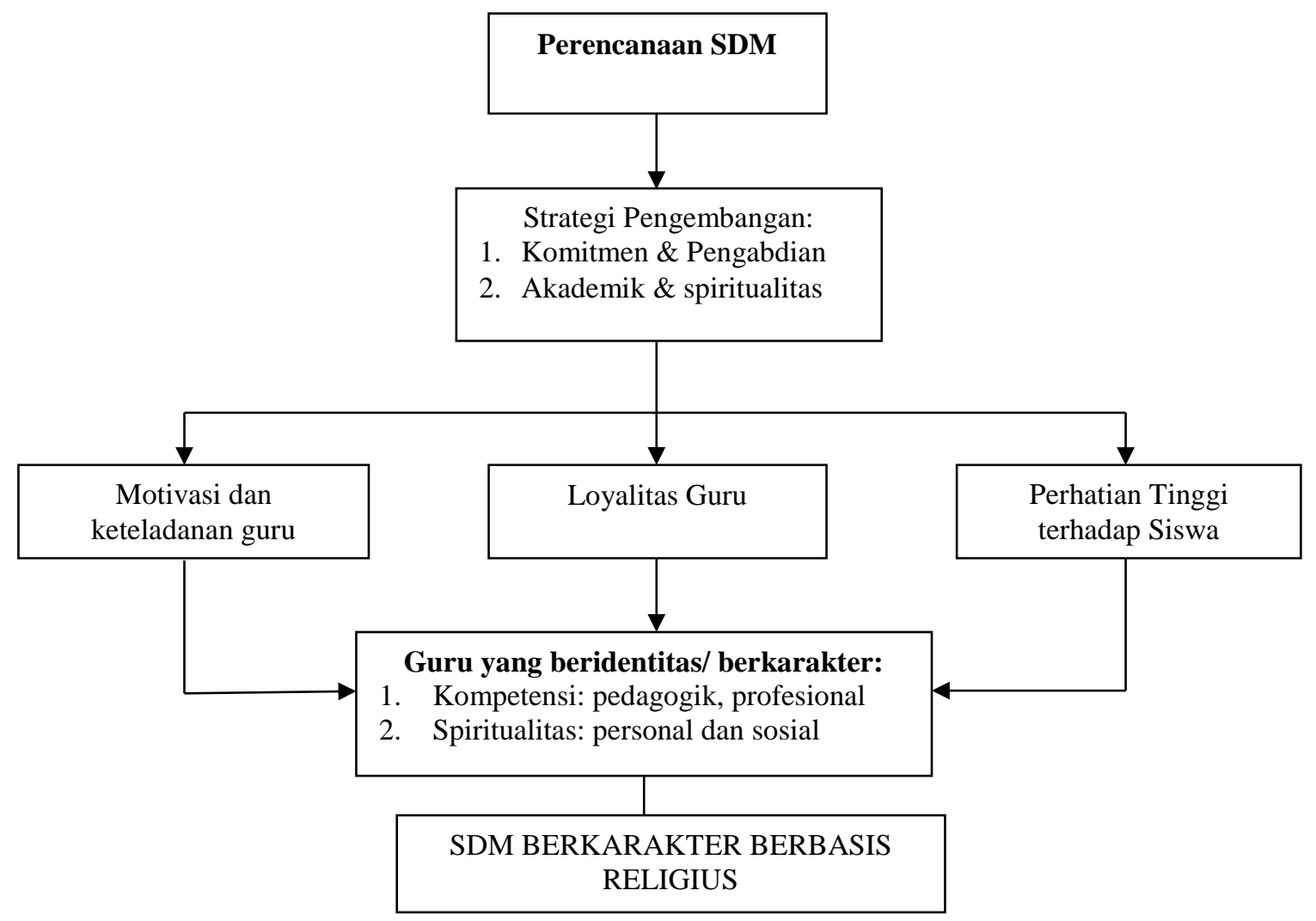


workshop bagi guru; 3) sosialisasi hasil pelatihan bagi guru lain; 4) keteladanan bagi guru: 5) ceramah agama rutin; 6) kegiatan doa bersama (zikrul jama'i); 7) kegiatan al qiyadah; dan 8) guru sebagai murabbi.

Dampak nyata dari pengembangan SDM guru di SD Islam Al Azhaar meliputi: 1) adanya motivasi dan keteladanan guru; 2) adanya loyalitas guru; dan 3) tingginya perhatian guru terhadap siswa. Temuan penelitian mengenai manajemen SDM berbasis kompetensi di SD Islam Al Azhaar Tulungagung dapat dilihat sebagaimana dalam gambar di bawah ini.

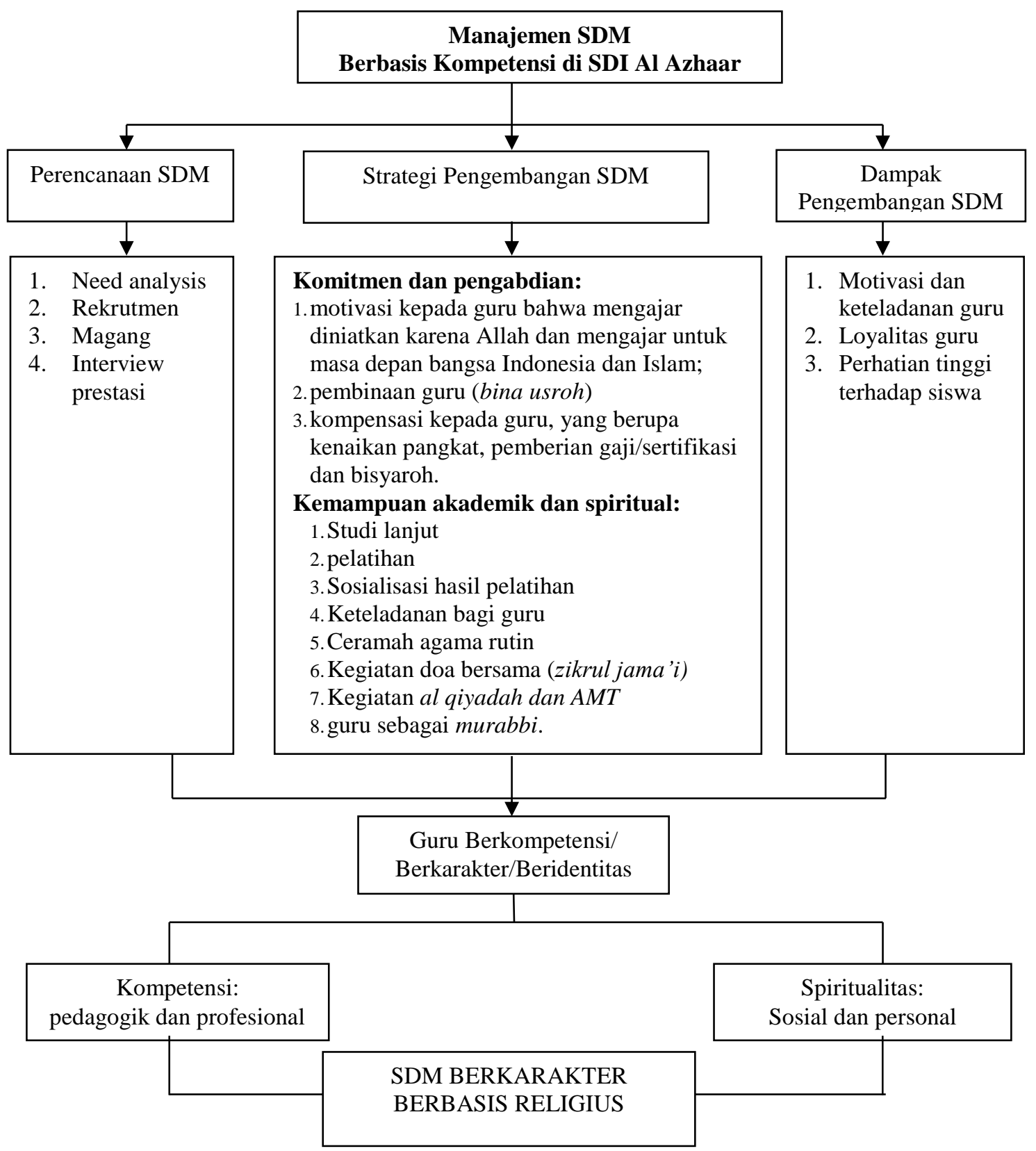


Perencanaan SDM Berbasis Kompetensi

Temuan penelitian mengenai perencanaan SDM guru berbasis kompetensi di SD Islam Al Munawwar sebagai berikut: 1) analisis kebutuhan guru; 2) rekrutmen guru; dan 3) seleksi guru.

Analisis kebutuhan guru merupakan langkah awal dalam mengembangkan kuantitas maupun kualitas guru. Untuk memperoleh calon guru yang kompeten, dilakukan rekrutmen guru SD Islam secara terbuka. Rekrutmen dengan memperhatikan kemampuan akademik, kualifikasi pendidikan dan hasil tes. Seleksi guru dilakukan oleh pihak sekolah, pihak Komite Sekolah, LPI, dan akademisi atau praktisi pendidikan serta psikolog. Seleksi guru juga dilakukan selama masa magang satu tahun. Dalam masa magang, guru dinilai dan dievaluasi mengenai kelayakan untuk diangkat sebagai guru. Tahapan perencanan SDM memperhatikan kompetensi yang dimiliki oleh calon guru, meliputi kualifikasi pendidikan (minimal S1), mampu membaca Al Quran dengan baik, memiliki pengetahuan/kemampuan akademik dan non akademik, memiliki pengalaman organisasi.

Temuan penelitian mengenai fokus perencanaan SDM berbasis kompetensi di SD Islam Al Munawwar Tulungagung dapat dilihat dalam gambar berikut:

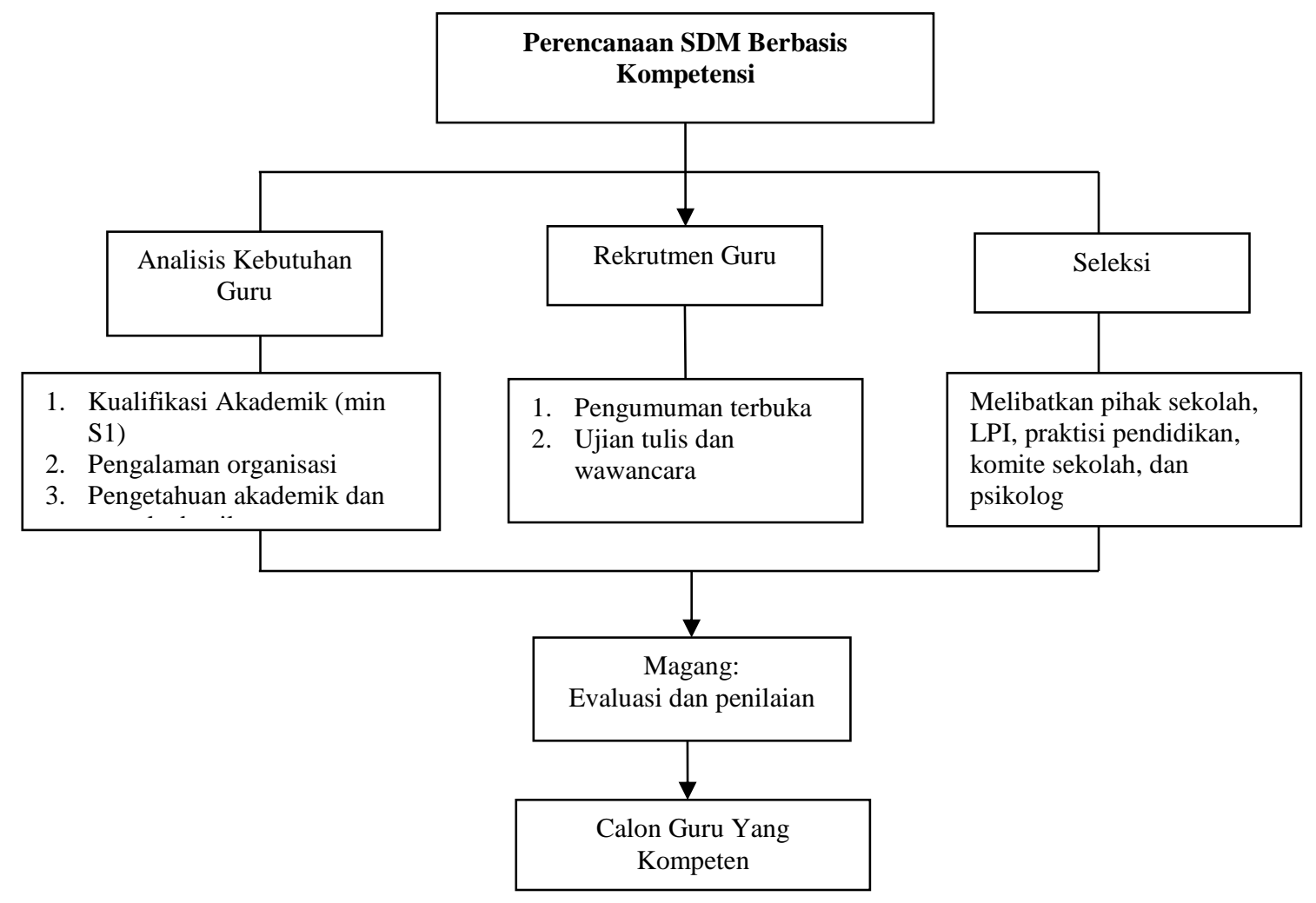




\section{Strategi Pengembangan SDM Guru Berbasis Kompetensi}

Strategi pengembangan SDM berbasis kompetensi di SD Islam Al Munawwar dilakukan melalui peningkatan: 1) komitmen dan pengabdian guru; dan 2) kemampuan akademik dan spiritualitas guru. Peningkatan komitmen dan pengabdian guru dilakukan melaui: 1) motivasi mengajar adalah amanah dari Allah SWT untuk mengembangkan syiar agama Islam dan amanah dari orang tua untuk mendidik anak menjadi anak yang cerdas dan berakhlak mulia; 2) silaturahmi antar guru dilakukan dengan model arisan dapat meningkatkan rasa persaudaraan sesame guru; 3) kompensasi dan penghargaan kepada guru: Asuransi pada usia pensiun merupakan kebijakan yang diambil oleh pengelola untuk meningkatkan rasa kepemilikan terhadap lembaga serta ucapan terima kasih lembaga terhadap guru; dan 4) pembinaan karir merupakan keniscayaan dalam sebuah organisasi.

Sedangkan

peningkatan

kompetensi akademik dan spiritual dilakukan dengan cara: 1) supervisi atau monitoring oleh komite sekolah dan/atau pakar pendidikan pihak eksternal dilakukan dalam evaluasi peningkatan kompetensi guru; 2) pelatihan baik oleh internal maupun eksternal dalam rangka peningkatan kompetensi para guru; 3) pembinaan guru secara berkesinambungan, di awal semester, awal tahun pelajaran, dan tiap bulan; 4) untuk menambah keimanan dan ketaqwaan melalui ceramah atau mauidhoh hasanah; 5) studi lanjut pada jenjang yang lebih tinggi; dan 6) ziarah wali, istighatsah dan doa bersama. Temuan penelitian di SD Islam Al Azhar Tulungagung berkaitan dengan fokus strategi pengembangan SDM berbasis kompetensi dapat dilihat dalam gambar berikut ini:

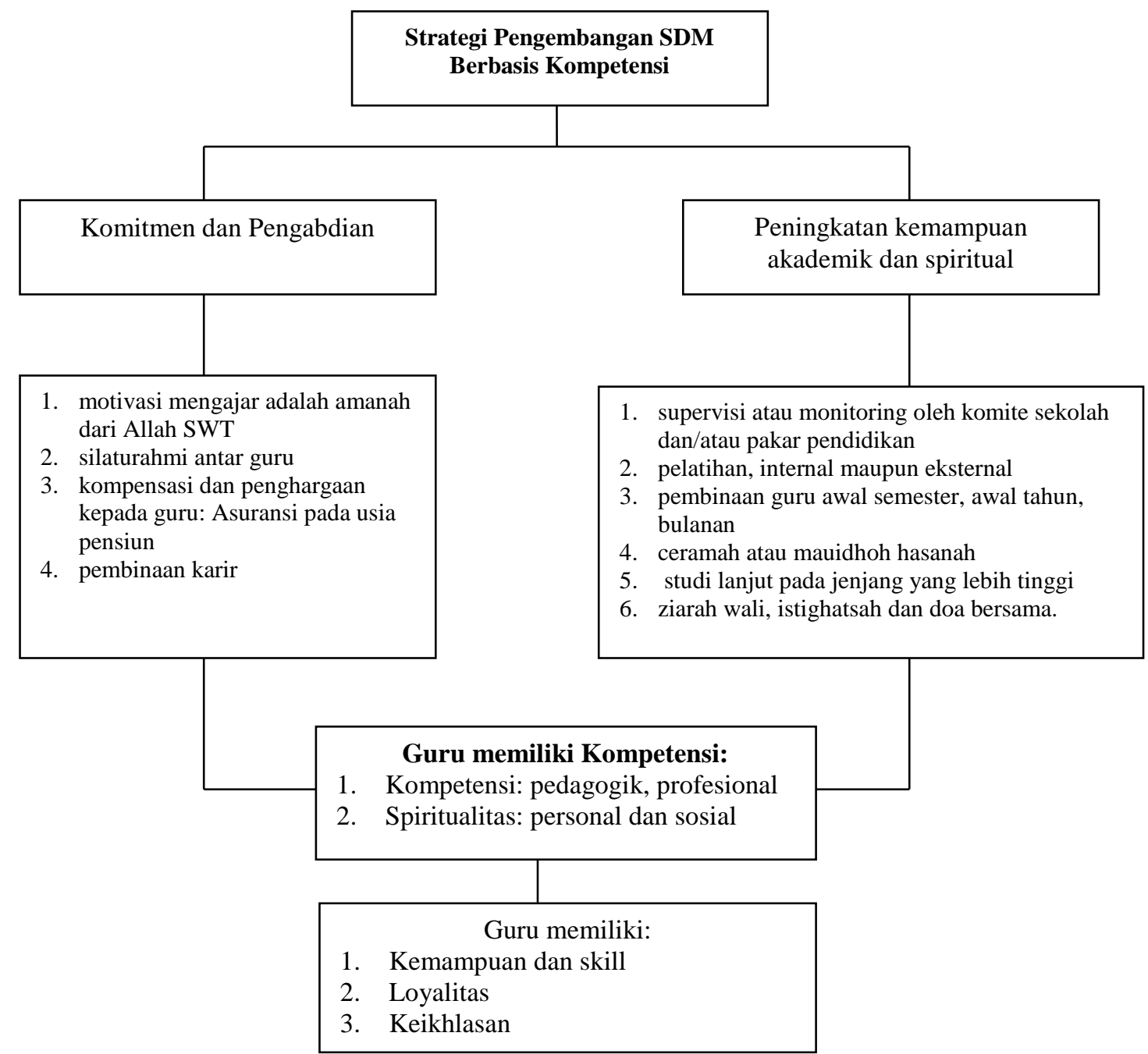




\section{Dampak Pengembangan SDM Guru Berbasis Kompetensi}

Dampak peningkatan akademik guru maka kemampuan dan keahlian guru menjadi meningkat. guru telah memiliki kemampuan dalam pengelolaan kelas, strategi belajar mengajar. Namun seiring dengan perkembangan kebijakan maupun teknologi, guru harus mampu beradaptasi serta terus mengembangkan kemampuannya

Nilai motivasi, keikhlasan, dan loyalitas para guru semakin meningkat. Motivasi dalam proses pembelajaran di SD Islam Al Munawwar adalah bernilai ibadah. Ibadah diyakini sebagai sebuah pengabdian, sebagaimana dalam Surat Adz Dzariyat ayat 56 yang artinya bahwa Allah tidak menciptakan Jin dan manusia melainkan hanya untuk beribadah kepada Nya. Mengajar juga menanamkan nilai keikhlasan. Jadi tidak sekedar materi yang sekarang akan didapatkan tetapi kelanjutannya sampai besok di akhirat.
Temuan penelitian mengenai fokus penelitian dampak pengembangan SDM berbasis kompetensi di SD Islam $\mathrm{Al}$ Munawwar dapat dilihat dalam gambar di bawah ini.

Sedangkan temuan penelitian tiap fokus yang berada di SD Islam Al Munawwar Tulungagung, maka dapat diperoleh hasil temuan penelitian secara keseluruhan mengenai manajemen SDM berbasis kompetansi di SD Islam Al Munawwar. Temuan penelitian tersebut dapat dilihat dalam gambar berikutnya.

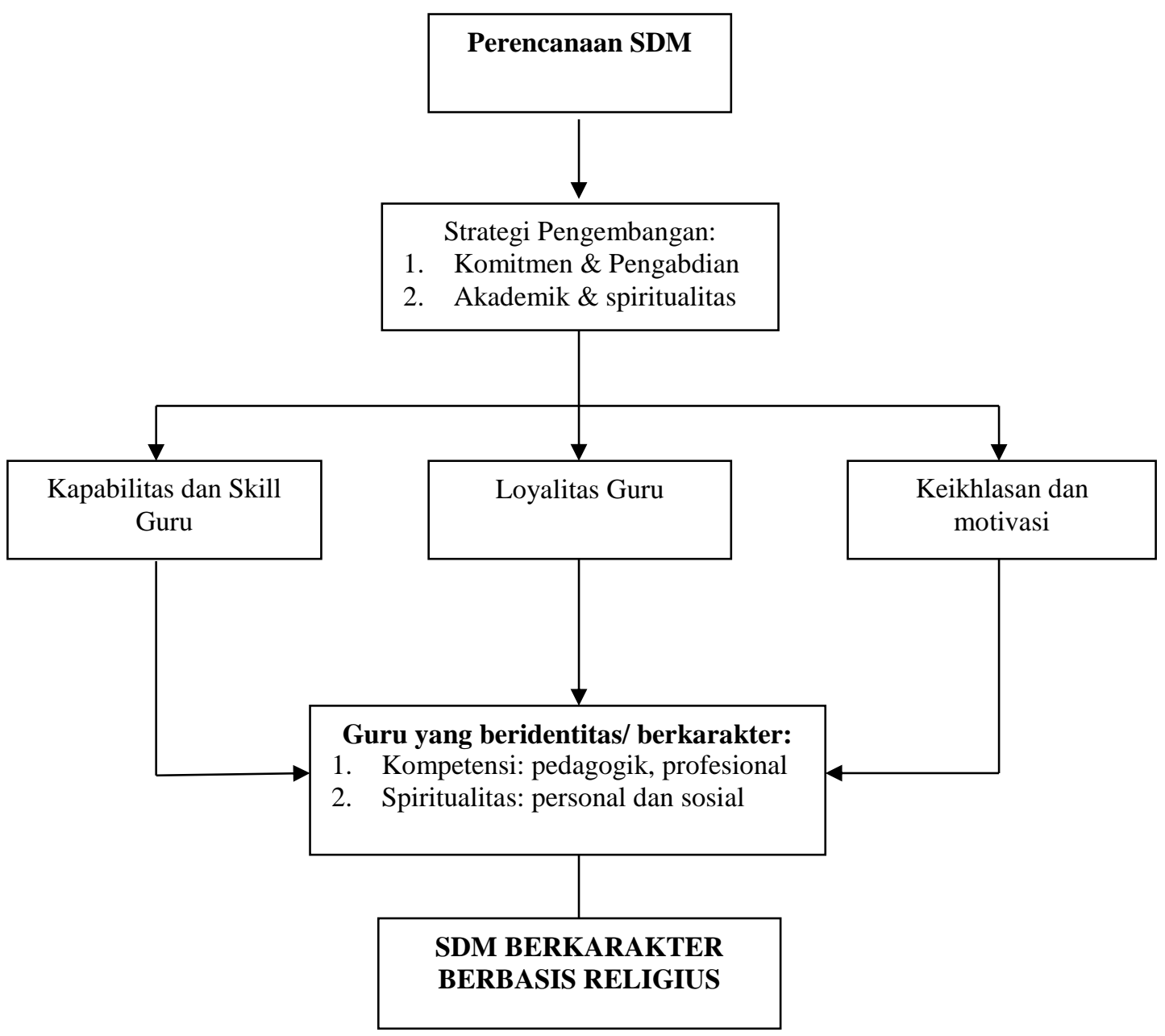




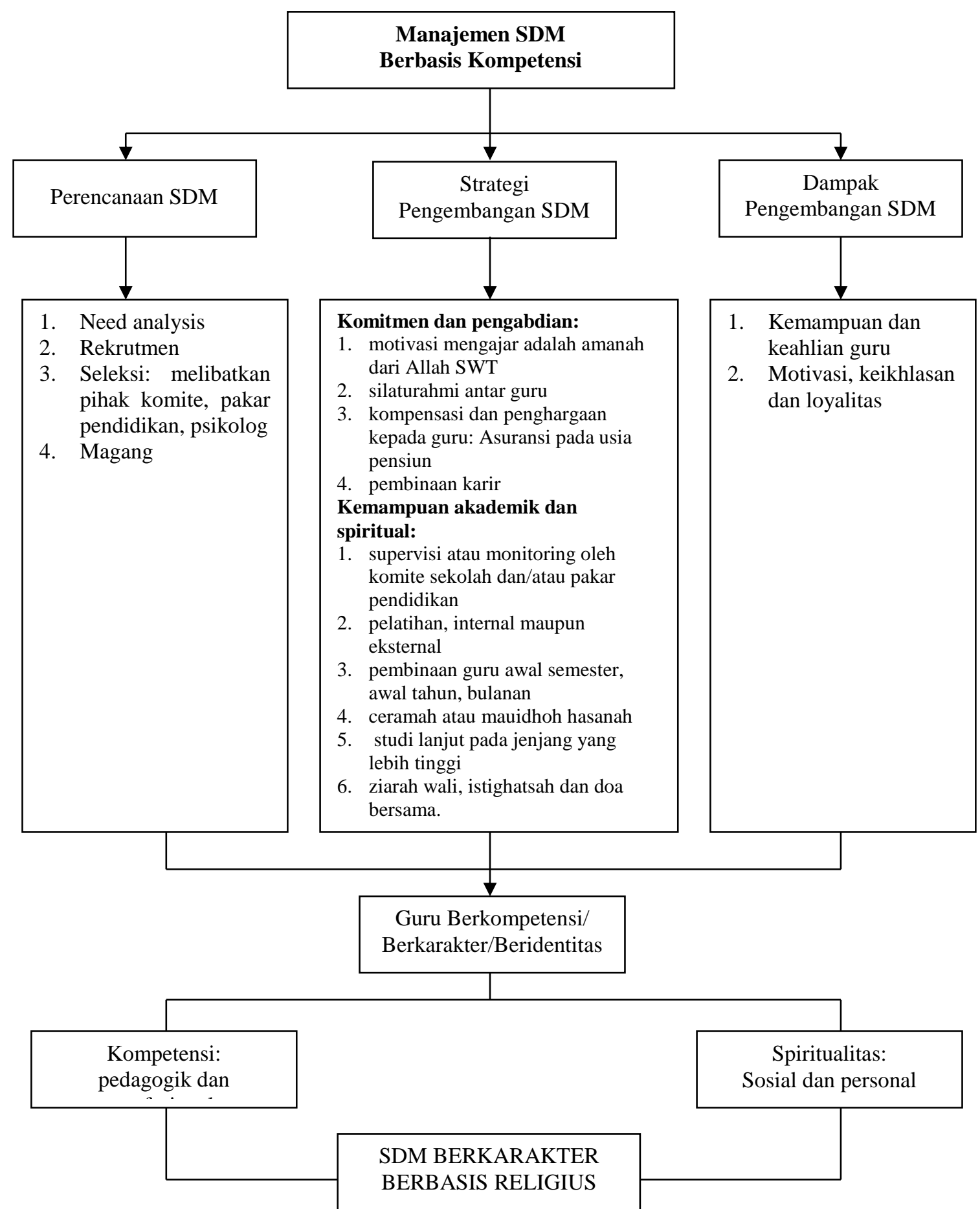

\section{Temuan Penelitian Lintas Situs}

\section{Perencanaan SDM Berbasis Kompetensi}

Sebagai sebuah lembaga pendidikan, baik SD Islam Al Azhaar maupun SD Islam Al Munawwar yang berusaha melaksanakan pola manajemen secara profesional, setiap tahun melaksanakan analisis jabatan dan kebutuhan tenaga pendidik dan tenaga kependidikan. Guru yang telah lama mengabdi diberikan promosi untuk megisi jabatan sebagai wali kelas atau jabatan lain. Selain itu, juga dilaksanakan analisis kebutuhan jumlah guru yang dibutuhkan untuk mengisi kekosongan. Hal ini disebabkan karena adanya guru yang tidak lolos seleksi dalam proses magang yang dilaksanakan di SD Islam Al Munawwar Tulungagung.

Sebagai bagian dari proses manajemen, perencanaan yang baik akan sangat menentukan keberhasilan suatu 
kegiatan atau tujuan. Apabila sudah ada perencanaan yang baik mengenai pengadaan guru di sekolah maka kebutuhan guru tidak akan terganggu. Selanjutnya proses belajar mengajar dapat terlaksana tanpa ada hambatan kekurangan guru.

Sebagai tindak lanjut perencanaan pengadaan guru di SD Islam Al Azhaar maka dilaksanakan rekrutmen guru. Pengadaan atau rekrutmen guru dilakukan sesuai dengan kebutuhan yang ada di SD slam Al Azhaar. Rekrutmen guru di SD Islam Al Azhaar juga mempertimbangkan input guru tersebut. Hal tersebut sesuai dengan yang tercantum dalam alur tenaga pengajar yang ada di SD Islam Al Azhaar. Mengenai alur tenaga pengajar di SD Islam AL Azhaar yang pertama adalah input guru, seleksi, pelatihan, dan selanjutnya tahapan menuju guru yang berhasil, yakni proses menjadi guru magang, capeg, guru tetap dan teman berjuang.

Proses rekrutmennya adalah tahapan seleksi. Seleksi dilaksanakan sebelum calon guru masuk di SD Islam Al Azhaar. Seleksi meliputi wawasan dan sikap kependidikan, wawasan dan sikap keislaman, penguasaan bidang studi, potensi akademis dan psikotes. Seleksi juga dilakukan dengan memberikan kesempatan calon guru untuk uji coba dalam melaksanakan proses belajar mengajar. Dalam proses ini juga dapat diketahui tingkat kerjasama peserta seleksi dan loyalitasnya.

Calon guru di SD Islam setelah melalui tahap wawancara, calon guru diikutkan pada tahap magang di SD Islam. Kriteria seleksi dalam tahap magang ini guru diseleksi melalui praktik mengajar dalam suatu mata pelajaran. Selain kriteria skill atau kompetensi pedagogik, calon guru juga dinilai tentang hubungan sosialnya serta tanggung jawabnya dalam menjalankan tugas-tugas lain di sekolah. Hal tersebut dilakukan di SD Islam Al Munawwar.

Sedangkan di SD Islam Al Azhaar dalam proses magang ada istilah interview prestasi Lebih lanjut, untuk proses interview prestasi ini diperlukan proses yang detail, tidak hanya persyaratan dokumen saja. Kepala Sekolah mengusulkan, kemudian dicari dan dikumpulkan data dari berbagai pihak (teman sejawat, para orang tua santri, kondisi kesehatannya). Juga dievaluasi berbagai kompetensinya. Jika semuanya baik, maka akan segera beralih status dan kepangkatannya.

Berdasarkan analisis di atas, perencanaan SDM guru di SD Islam menggunakan pendekatan kompetensi berbasis religius. Langkah-langkah yang digunakan adalah a) analisis kebutuhan; b) penentuan standar kualifikasi pendidik (akademis, religius, pengalaman, motivasi dan dakwah), c) seleksi, dengan open system selection, d) magang dan evaluasi, e) memiliki kompetensi, motivasi dan komitmen pengabdian.

Dari uraian di atas, dapat di rangkum dalam bentuk tabel perbandingan temuan penelitian pada fokus perencanaan SDM berikut ini. 
Tabel Temuan Penelitian Perencanaan SDM

\begin{tabular}{|c|c|c|}
\hline Temuan di SDI Al Azhaar & $\begin{array}{l}\text { Temuan di SDI Al } \\
\text { Munawwar }\end{array}$ & Temuan penelitian \\
\hline $\begin{array}{l}\text { Untuk mengembangkan } \\
\text { SDM berbasis kompetensi } \\
\text { harus dilakukan } \\
\text { perencanaan dengan } \\
\text { menganalisis kebutuhan } \\
\text { sesuai kualifikasi, } \\
\text { kapabilitas dan skill yang } \\
\text { dibutuhkan, punya } \\
\text { religiusitas baik. } \\
\text { Pengadaan guru dilakukan } \\
\text { dengan merekrut tenaga } \\
\text { baru melalui rekrutmen } \\
\text { dan seleksi. Seleksi } \\
\text { dilakukan dengan sistem } \\
\text { magang atau interview } \\
\text { prestasi }\end{array}$ & $\begin{array}{l}\text { Perencanaan dilakukan } \\
\text { dengan analisis kebutuhan } \\
\text { yang disesuaikan dengan } \\
\text { standar kualifikasi dan } \\
\text { kapabilitas serta pengalaman } \\
\text { dengan kebutuhan. } \\
\text { Pengadaan dengan } \\
\text { rekrutmen dan seleksi } \\
\text { dengan melibatkan pihak } \\
\text { eksternal, seperti komite, LPI, } \\
\text { pakar pendidikan dan } \\
\text { psikolog }\end{array}$ & $\begin{array}{l}\text { Perencanaan SDM dilakukan } \\
\text { dengan analisis kebutuhan } \\
\text { yang disesuaikan dengan } \\
\text { standar kualifikasi, } \\
\text { kapabilitas, dan pengalaman. } \\
\text { Pengadaan dilakukan dengan } \\
\text { rekrutmen yang terbuka, } \\
\text { dengan standar kualifikasi } \\
\text { pendidikan, kapabilitas, } \\
\text { pengalaman dan religiusitas. } \\
\text { Seleksi dilakukan dengan } \\
\text { sistem magang dengan } \\
\text { mengevaluasi komitmen dan } \\
\text { kemampuannya. }\end{array}$ \\
\hline
\end{tabular}

\section{Strategi Pengembangan SDM Berbasis Kompetensi}

Untuk menjadi guru yang profesional, mencerminkan keempat kompetensi guru yang telah ditetapkan dalam Undang Undang RI No.14 Tahun 2005 dalam kinerja keseharian, guru juga harus memiliki rasa kepemilikan dan komitmen yang tinggi, serta pengabdian terhadap agama, sekolah dan anak didik. Setelah kita lihat dalam paparan data mengenai komitmen dan pengabdian guru di SD Islam Al Azhaar dan SD Islam Al Munawwar, maka dapat diketahui bahwa terdapat berbagai cara yang dilakukan oleh pimpinan sekolah untuk meningkatkan komitmen dan pengabdian guru.

Untuk membina guru baru di sekolah, baik SD Islam Al Azhaar maupun SD Islam Al Munawar, menerapkan sistem seleksi alam yang disebut sebagai guru magang. Guru magang di SD Islam $\mathrm{Al}$ Munawwar berlangsung selama satu tahun, dievaluasi secara bersama-sama oleh Komite Sekolah, LPI dan Kepala Sekolah. Dalam evaluasi ini sistem yang biasa dilakukan adalah kunjungan langsung ke kelas untuk melakukan supervisi kelas pada guru magang tersebut. Dari sini dapat dilihat bagaimana kemampuan guru dalam mengelola kelas di sekolah. Selain itu, evaluasi bagi guru magang juga dilihat dari aktivitas keseharian guru tersebut. Apabila dinilai layak dan memiliki komitmen serta pengabdian yang tinggi terhadap sekolah, maka dalam waktu satu tahun dapat diangkat menjadi calon guru tetap Yayasan, dan selanjutnya dalam waktu 1 tahun dapat diangkat menjadi guru tetap Yayasan.

Sedangkan proses guru magang di SD Islam Al Azhaar, berlangsung apabila guru tersebut dalam evaluasi kesehariannya baik, maka dalam waktu 3 bulan dapat diangkat menjadi calon pegawai di LPI Al Azhaar. Kemudian dalam waktu 8 bulan sampai satu tahun, guru yang bersangkutan dapat dinaikkan menjadi guru tetap Yayasan. Untuk menjadi guru tetap yayasan ini, selain evaluasi dari monitoring keseharian guru dan data dokumentasi yang dimiliki guru, juga ada evaluasi dari teman sejawat di sekolah dan para orang tua santri. Evaluasi berkesinambungan dalam rangka kenaikan 
kepangkatan guru tersebut di SD Islam Al Azhaar disebut dengan interview prestasi.

Al Munawwar juga diperhatikan. Untuk guru yang telah memiliki masa pengabdian lama, dan memiliki kompetensi, direkomendasikan untuk mengikuti sertifikasi guru. Dan di SDI Al Azhaar maupun di SDI Al Munawwar lebih darilima guru juga telah mendapatkan sertifikasi guru. Di SD Islam Al Munawwar guru senior juga diusahakan untuk mendapatkan dana pensiun sebagai bentuk penghargaan atas pengabdian dan prestasi yang diberikan. Sedangkan di LPI Al Azhaar telah diatur dan dilaksanakan insentif bulanan bagi tenaga pensiunan.

Keakraban, kebersamaan dan kenyamanan serta ketenangan guru dalam menjalankan tugas di lembaga pendidikan Islam memunculkan semangat untuk berjuang di jalan Allah melalui pendidikan. Di SD Islam Al Azhaar, kebersamaan di antara para guru dalam mengembangkan kemampuan mengajar, melakukan dakwah di dunia pendidikan anak, beribadah di jalan Allah dengan kegiatan mendidik dan mengajar, mampu membangun kemauan bersama yang diwujudkan menjadi teman berjuang di antara para guru di sana.

Dalam membina guru yang mampu membimbing anak didiknya belajar di sekolah, senantiasa disampaikan ceramah agama atau siraman rohani bagi para guru dan tenaga kependidikan. Di SD Islam Al Munawwar, pembinaan rohani biasanya disampaikan oleh pengelola Pondok Pesantren dan akademisi atau pemerhati pendidikan, atau pihak lain dari luar. Sementara itu di SD Islam Al Azhaar, pembinaan rohani sering diisi oleh Direktur LPI Al Azhaar, atau pimpinan LPI lainnya, dan mendatangkan para pimpinan pondok pesantren dari luar, para praktisi pendidikan Islam, seperti UIN MMI Malang, pondok Haromain Pujon, bahkan sering juga mengunjungi tempat atau pengajian di luar kota.
Dalam rangka meningkatkan kemampuan kepemimpinan para guru, baik di SD Islam Al Azhaar maupun di SD Islam Al Munawwar, sekolah mendelegasikan dan memberikan amanah para guru untuk menjadi panitia atau pengelola kegiatan tertentu. Di SD Islam Al Munawwar, karakter kepemimpinan ditanamkan melalui tugas menjadi panita PHBI atau PHBN, menjadi wali kelas dan pengelola mading kelas. Di SD Islam Al Azhaar, selain menjadi panitia kegiatan seperti workshop dan seminar, juga ditugaskan menjadi pemandu workshop, penyusunan silabi atau RPP, utamanya guru yang telah berstatus profesional (mendapatkan sertifikasi).

Kegiatan pembinaan spiritual para guru dilaksanakan secara rutin. Setiap bulan, di SD Islam Al Azhaar dilaksanakan Bina Usroh atau bina keluarga. Selain Bina usroh juga dilaksanakan pembinaan mental keagamaan setiap hari Jumat. Sedangkan di SD Islam Al Munawwar pembinaan melalui ceramah agama setiap bulan. Bentuk kegiatan di SD Islam Al Azhaar dalam Bina keluarga dan acara besar lainnya, dengan bentuk ceramah dan mengumandangkan dzikir Jama'i. Sedangkan di SD Islam Al Munawwar dilaksanakan dengan Yasinan, mengirim doa kepada ahli kubur, dan membaca istighostah bersama

Dari analisis lintas situs di atas, dapat diketahui bahwa strtegi pengembangan SDM di SD Islam dilakukan dengan mengintegrasikan continous training and development (CTD), evaluasi kinerja dan membangun semangat integrasi dakwah dan pendidikan. Sasaran pengembangan SDM meliputi aspek peningkatan komitmen dan pengabdian dan komitmen, dan aspek peningkatan kemampuan akademik dan spiritual guru. Tabel rangkuman temuan penelitian lintas situs tentang strategi pengembangan SDM berbasis kompetensi 
Tabel Temuan Penelitian Strategi pengembangan SDM

\begin{tabular}{|c|c|c|}
\hline Temuan di SDI Al Azhaar & $\begin{array}{l}\text { Temuan di SDI Al } \\
\text { Munawwar }\end{array}$ & Temuan penelitian \\
\hline $\begin{array}{l}\text { Peningkatan komitmen dan } \\
\text { pengabdian dilakukan } \\
\text { dengan: } \\
\text { 1. Pembinaan Guru dan } \\
\text { keluarga (Bina Usroh) } \\
\text { 2. Memberikan kompensasi } \\
\text { kepada guru (pangkat, gaji } \\
\text { dan bisyaroh) } \\
\text { 3. Silaturahmi antar guru } \\
\text { Peningkatan kemampuan } \\
\text { akademik dan spiritual } \\
\text { 1. Peningkatan jenjang } \\
\text { pendidikan guru } \\
\text { 2. Pelatihan dan workshop bagi } \\
\text { guru } \\
\text { 3. Sosialisasi hasil pelatihan } \\
\text { bagi guru lain } \\
\text { 4. Keteladanan (kepemimpinan) } \\
\text { bagi guru } \\
\text { 5. Memberikan Motivasi kepada } \\
\text { Guru, bahwa mengajar adalah } \\
\text { demi masa depan bangsa } \\
\text { Indonesia dan masa depan } \\
\text { umat Islam, dan mengajar } \\
\text { diniatkan ibadah kepada } \\
\text { Allah SWT } \\
\text { 6. Ceramah agama rutin } \\
\text { 7. Kegiatan Doa (dzikrul jama'i) } \\
\text { 8. Al Qiyadah dan AMT } \\
\text { (Achievment Motivation } \\
\text { Training) } \\
\text { 9. Guru sebagai murabbi }\end{array}$ & $\begin{array}{l}\text { Peningkatan komitmen } \\
\text { dan pengabdian dilakukan } \\
\text { dengan: } \\
\text { 1. Silaturahmi antar guru } \\
\text { 2. Kompensasi dan } \\
\text { penghargaan kepada } \\
\text { guru: Asuransi pada usia } \\
\text { pensiun } \\
\text { 3. Pembinaan karir } \\
\text { Peningkatan kemampuan } \\
\text { akademik dan spiritual } \\
\text { 1. Supervisi oleh Komite } \\
\text { Sekolah } \\
\text { 2. Pelatihan dan Workshop } \\
\text { 3. Pembinaan para guru } \\
\text { dalam bentuk:, awal } \\
\text { tahun, bulanan dan awal } \\
\text { semester. Kegiatan } \\
\text { refreshing di luar } \\
\text { (ouutbond) } \\
\text { 4. Motivasi bahwa menjadi } \\
\text { Guru adalah Amanah } \\
\text { 5. Pengajian dan Pondok } \\
\text { Ramadlan bagi Guru } \\
\text { 6. Ziarah Wali, Istighatsah } \\
\text { dan doa bersama }\end{array}$ & $\begin{array}{l}\text { Peningkatan komitmen } \\
\text { dan pengabdian dilakukan } \\
\text { dengan: } \\
\text { 1. pemberian kompensasi } \\
\text { 2. pengembangan karir, } \\
\text { 3. pembinaan pribadi dan } \\
\text { keluarga, } \\
\text { 4. silaturahmi antar guru } \\
\text { Peningkatan kemampuan } \\
\text { akademik dan spiritual } \\
\text { 1. Pelatihan dan sosialisasi, } \\
\text { 2. Supervisi dan keteladanan } \\
\text { pimpinan } \\
\text { 3. Studi lanjut } \\
\text { 4. Motivasi bekerja adalah } \\
\text { ibadah } \\
\text { 5. Doa bersama/ istighotsah } \\
\text { 6. Pengajian/ceramah agama } \\
\text { 7. Mendekatkan diri kepada } \\
\text { Allah (al qiyadah) }\end{array}$ \\
\hline
\end{tabular}

\section{Dampak Pengembangan SDM Berbasis Kompetensi}

Motivasi dalam proses pembelajaran di SD Islam Al Munawwar maupun di SD Islam Al Azhaar adalah bernilai ibadah. Ibadah diyakini sebagai sebuah pengabdian, sebagaimana dalam Surat Adz Dzariyat ayat 56 yang artinya bahwa Allah tidak menciptakan Jin dan manusia melainkan hanya untuk beribadah kepada Nya.
Di sisi yang lain, setelah motivasi beribadah dalam proses pembelajaran maka akan menumbuhkan jiwa keikhlasan pada diri guru Konteks ini dalam penyelenggaraan pendidikan Islam dapat dilakukan oleh penyelenggara (yayasan, kepala sekolah, guru) dan juga dilakukan oleh peserta didik. Dengan landasan ini hendaknya pengelola (kepala sekolah, guru) dalam mendidik didasarkan oleh nilai ibadah dan pendidikan hendaknya mengarahkan peserta didik untuk menjadi ahli ibadah. 
Loyalitas guru-guru di SD Islam Al Azhaar dan SD Islam Al Munawwar tidak hanya dilandasi oleh adanya kesejahteraan atau tunjangan dari lembaga melainkan adanya kesamaan visi berjuang di jalan Allah melalui media pendidikan. Selain itu loyalitas guru di SD Islam Al Azhaar ini ditunjukkan dengan adanya wakaf berupa tanah di sekitar gedung $\mathrm{Al}$ Azhaar saat ini. Jadi dengan indikator pemberian tanah wakaf ini loyalitas Al Azhaar sudah tidak diragukan lagi. Apalagi dalam melaksanakan pembelajaran sebenarnya mereka rela dan ikhlas andaikan tidak dibayar. Tetapi sebagai bentuk ucapan terima kasih dari lembaga kami memberikan sebagai ganti keringat perjuangan mereka sesuai dengan yang kami mampu.
Berdasarkan analisis lintas situs di atas, dapat diketahui bahwa dampak pengembangan SDM akan diperoleh guru yang memiliki motivasi kerja tinggi, mampu menjadi teladan bagi siswa, memiliki loyalitas tinggi dan memiliki komitmen terhadap perhatian dan pelayanan terbaik kepada siswa. Dari hal ini akan dilahirkan guru yang memiliki integritas atau karakter berbasis religius.

Temuan penelitian lintas situs tentang dampak pengembangan sumber daya manusia (SDM) dapat dilihat juga dalam gambar di bawah ini.

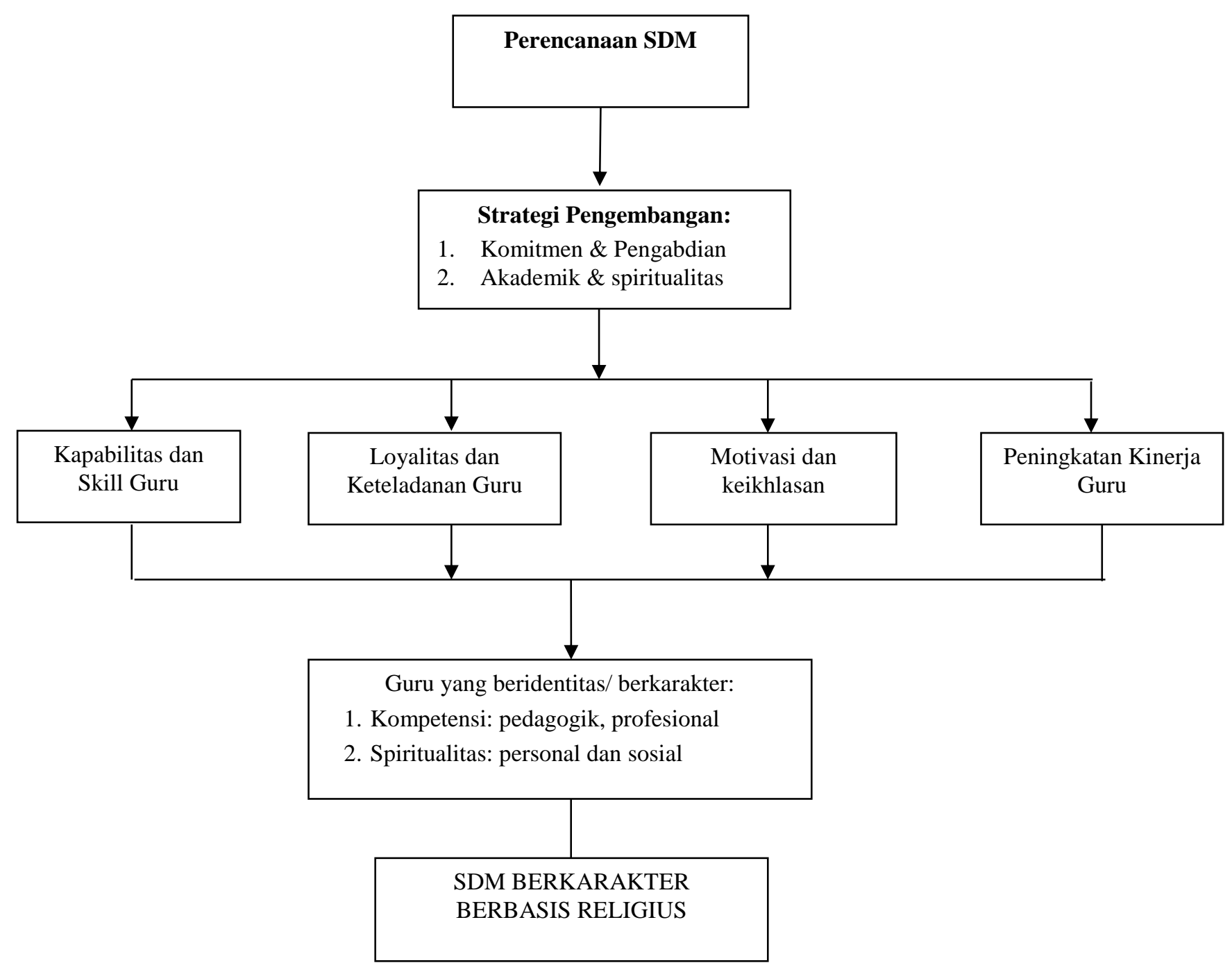


Dari temuan penelitian tiap fokus di atas maka akan diperoleh temuan penelitian mengenai manajemen sumber daya manusia berbasis kompetensi di SD Islam. Manajemen SDM berbasis kompetensi merupakan rangkaian kegiatan yang diawali dari proses perencanaan SDM dilanjutkan dengan strategi pengembangan SDM dan hasil dari pengembangan SDM berbasis kompetensi. Rangkaian kegiatan tersebut meliputi input, proses dan output. Hasil penelitian dalam manajemen SDM berbasis kompetensi di SD Islam adalah dilahirkannya sumber daya manusia (SDM) berkarakter berbasis religius.

\section{Perencanaan Sumber Daya Manusia Berbasis Kompetensi}

Perencanaan sumber daya manusia (SDM) sangat berpengaruh pada kelangsungan suatu lembaga pendidikan Islam. Pendidikan harus mampu menyiapkan sumber daya manusia (SDM) yang tidak sekedar sebagai penerima arus informasi global, tetapi juga harus memberikan bekal kepada siswa agar dapat mengolah, menyesuaikan dan mengembangklan segala hal yang diterima melalui arus informasi itu yakni manusia yang kreatif dan produktif. Oleh karena itu lembaga pendidikan Islam harus benarbenar merencanakan SDM jika masih ingin ikut serta dalam persaingan pendidikan yang sangat kompetitif.

Pada umumnya proses perencanaan sumber daya manusia dibagi dua tahapan, yaitu tahapan perkiran kebutuhan SDM (needs forcasting) dan perencanaan program (program planning). Perkiraan kebutuhan tersebut diturunkan dari sejumlah informasi seperti analisis kondisi eksternal, kemampuan SDM yang dimiliki organiasasi, potensi SDM, anggaran dan lain-lain. Sedangkan perencanaan program sebagaimana diungkapkan James Walker meliputi manajemen kinerja dan manajemen karier (Suwatno dan Donni Juni Priansa, 2013: 48) .

Perencanaan SDM ini, di SD Islam Al Azhaar Tulungagung dan di SD Islam Al Munawwar Tulungagung dilakukan baik dalam tahapan kebutuhan maupun perencanaan program. Perencanaan kebutuhan guru dilakukan dengan rekrutmen guru, sedangkan perencanaan program dilakukan dengan merencanakan kegiatan yang dapat meningkatkan kompetensi guru, seperti pembinaan, training, pertemuan, dan lain-lain.

Hal itu dimaksudkan bahwa perencanan adalah proses awal untuk menentukan langkah dalam menghadapi berbagai kemungkinan masa depan, memastikan tujuan yang hendak dicapai, dalam fase-fase waktu yang pasti sesuai dengan skala prioritas tertentu. Hal ini dapat dimengerti mengingat tanpa sebuah perencanaan yang baik suatu pekerjaan tidak akan pernah sampai pada tujuan yang diharapkan. Perencanaan adalah keniscayaan bagi yang ingin berhasil tidak terkecuali bila seorang muslim mengharapkan ridha dan surga dari Allah SWT.

\section{Strategi Pengembangan Sumber Daya Manusia Berbasis Kompetensi}

\section{Peningkatan Komitmen dan Pengabdian Guru}

SDM yang dibutuhkan oleh lembaga pendidikan Islam merupakan SDM yang unik. Suprayoga mengatakan bahwa usaha untuk mengidentifikasi SDM yang unggul dibutuhkan oleh pendidikan Islam adalah SDM yang unik. SDM dalam lembaga pendidikan Islamdiperlukan SDM yang memiliki komitmen dan pengabdian terhadap organisasi. Oleh karena itu diperlukan strategi dalam pengembangan SDM di lembaga pendidikan Islam.

Griffin juga menjelaskan mengenai kepuasan dan moral atau semangat juang. Dalam teori job satisfaction, ia mengatakan bahwa kesenangan yang diperoleh seseorang dapat berasal dari penyelesaian pekerjaannya. Dari sini dapat dikatakan bahwa moral atau semangat juang merupakan keseluruhan sikap yang dimiliki oleh karyawan terhadap tempat kerja mereka. Dalam penelitian ini dapat dilihat interaksi antara pimpinan di jenjang SDI Al Azhaar, interaksi guru dengan pimpinan di atasnya, sikap guru dengan guru-guru lainnya yang menunjukkan 
adanya kepuasan dan motivasi mereka di tempat kerja.

Kepuasan dan motivasi didasarkan pada psychological contract in organisation. Hal ini, sebagaimana hasil penelitian bahwa dengan adanya pertemuan dan pembinaan rutin per jenjang, guru merasa selalu di arahkan dan dipahamkan tugastugasnya, dibimbing menuju penyelesaian tugas kepemimpinan pendidikan. Semua materi yang diterima, setelah itu diaplikasikan di jenjang SD, dan menjalankan kepemimpinan yang diamanahkan dengan penuh rasa aman. Hal ini pula menunjukkan kalau LPI Al Azhaar mengaplikasikan manajemen partisipatif dan pemberdayaan.

Lembaga pendidikan Islam merupakan media dan wahana untuk melestarikan budaya Islam. Oleh karena itu, di lembaga pendidikan Islam harus dikembangkan nilai-nilai keislaman. Kebudayaan suatu umat merupakan tulang punggung keberadaan dan keberlangsungan umat tersebut. Di atas kebudayaan dibangun peradaban umat, ditentukan target dan tujuannya, serta dibedakan dengan corak kehidupannya. Kebudayaan Islam adalah pengetahuan yang menempatkan aqidah Islam sebagai induk bahasan, baik untuk pengetahuan yang mengandung akidah Islam (seperti tafsir hadits), maupun pengetahuan yang dibutuhkan untuk memahami apa yang terpancar dari aqidah Islam, yang berupa hukum-hukum, termasuk hukum dalam melaksanakan pendidikan.

Dalam peningkatan komitmen dan pengabdian guru yang dilakukan adalah pemberian motivasi. Motivasi merupakan istilah yang lebih umum digunakan untuk mengantikan terma "motif-motif" dalam bahasa inggris disebut motive, berasal dari kata motion yang berarti gerakan atau sesuatu yang bergerak. Oleh karena itu term motif erat hubungan dengan gerak yang dilakukan manusia atau disebut perbuatan atau juga tingkah laku.

Motif dalam psikologi berarti rangsangan dorongan, atau pembangkit tenaga bagi terjadinya tingkah laku. Motivasi berarti rangsangan atau dorongan atau pembangkit tenaga bagi tingkah laku. Motivasi lebih berarti menunjuk kepada seluruh proses gerakan di atas, termasuk situasi yang mendorong melakukan perbuatan, dan dorongan yang timbul dalam diri individu. Situasi tersebut serta tujuan akhir dan gerakan atau perbuatan yang menimbulkan terjadinya tingkah laku (Ramayulis, 2002: 102).

Dalam Islam, motivasi ini dikaitkan dengan niat, sebagaimana hadits Nabi yang artinya segala sesuatu tergantung pada niatnya. Niat bisa diartikan dengan motif. Pengertian niat ada dua pengertian yaitu getaran batin untuk menentukan jenis perbuatan ibadah seperti sholat subuh, tahiyatul masjid dan lain-lain. Niat yang kedua dalam arti tujuan adalah maksud dari sesuatu perbuatan (motif).

Ketika motivasi dikaitkan dengan niat, kemudian niat dikaitkan dengan keikhlasan maka hal ini sangat sulit diukur. Namun yang perlu digarisbawahi terlepas dari keikhlasan dan riya ketika motivasi itu dibahas dan dibicarakan maka ada persamaannya yaitu sama-sama sulit diklaim secara mutlak namun hanya bisa diprediksi kemungkinannya. Manusia diciptakan tidak lain hanyalah untuk beribadah pada Allah. Semua aspek kehidupan bisa bernilai ibadah ketika diniatkan karena Allah. Oleh karena itu, sebagai lembaga pendidikan Islam, SD Islam Al Azhaar dan SD Islam Al Munawwar senantiasa menanamkan pada seluruh guru dan tenaga kependidikan bahwa apa yang dilakukan di lembaga harus diniati dengan ibadah, semata-mata karena Allah SWT. Selain itu, juga dikembangkan integrasi antara dakwah dengan tujuan pendidikan atau pengembangan keilmuan.

\section{Peningatan Kemampuan Akademik dan Spiritual Guru}

Usaha untuk membangun kompetensi insani bagi tenaga pendidik dengan menitiktekankan pandangan bahwa pendidikan merupakan kontribusi mental dan spiritual, merupakan proses manusia untuk menjadi sempurna yang diridloi Allah SWT, berkemampuan meningkatkan kompetensi spiritual untuk menjadi problem solver. Sebagai individu yang sejak kelahirannya menyandang gelar 
khalifah fil ardl, sebagai pemimpin akan dimintai pertanggungjawaban terhadap apa yang dipimpinnya.

Dengan mempertimbangkan tugas dalam proses transformasi tersebut maka sepanjang proses berjalan dibutuhkan figur pelaku yang memiliki kompetensi dan kepercayaan. Dunia pendidikan membutuhkan keteladanan, sosok guru yang bersifat welas asih, berorientasi pada nilai- nilai akhlak mulia yang tercermin dalam sikap dan perilaku keseharian di sepanjang interaksi edukatif yang diembannya (Muhammad Antonio Syafi'I, 2007: 50).

Berdasarkan analisis dalam paparan data di lokasi penelitian, dapat diketahui pula bahwa karakteristik guru yang harus dimiliki oleh para guru SD Islam utamanya adalah mengikuti pribadi Rasulullah SAW. Sikap tegas dan bijaksana, serta lembut sebagaimana yang dicontohkan oleh Kholifah Umar bin Khattab, merupakan pribadi yang memiliki sifat tegas, bijaksana dan juga memiliki kelembutan.

Guru harus mampu menjalin hablum minan naas yang penuh warna silaturahmi. Pertimbangan perasaan dan adab, memperluas recognition, pengenalan permasalahan dengan memperluas pengamatan, bersedia tabayyun dengan mencari jawaban dari pertanyaan apa (what), mengapa begitu (why) sampai mendapatkan data yang proporsional. Akhirnya dapat menemukannya, dan melahirkan banyak jalan untuk memecahkan masalah (how). Jiwa problem solver sebagai agenda hidup bersama, bahwa sebaik-baik manusia adalah yang memberi manfaat bagi sesamanya.

Untuk membangun potensi spiritual para guru, mereka juga harus memonitoring dan evaluasi terhadap potensi qiyadah, kemampuan mengemban visi dan misi lembaga, kesediaan menggalang kerjasama dan kebersamaan hidup. Selain itu, pribadi guru yang memiliki spiritual religious dapat ditandai ketika kualitas muslim, mukmin dan muhsin yang ditapaki dalam ibadah seharihari telah berbuah dalam wujud perilaku amar ma'ruf nahi munkar, dan perilaku watawa shoubil haqqi watawa shoubis shobr.

Untuk meningkatkan mutu sekolah Islam salah satu caranya adalah menjadikan keberadaan guru sebagai dai. Guru sebagai dai memiliki beberapa pilar, yaitu guru harus memiliki komitmen dakwah yang dapat mensucikan niat atau motivasi dan melahirkan cita-cita. Selanjutnya tugas dai yang pertama adalah mewujudkan izzul Islam wal muslimin. Kemudian dai harus berprinsip ibadah sehingga guru dalam mengajar adalah dalam rangka beribadah kepada Allah. Selanjutnya pilar guru sebagai dai adalah tanggung jawab guru kepada Allah dari dunia sampai akhirat.

Pengabdian kepada Tuhan, pengabdian kepada negara, pengabdian kepada masyarakat, dan pengabdian kepada jiwa-jiwa siswa yang membutuhkan bantuan dalam menggapai beraneka Ilmu pengetahuan. Oleh karena itu, strategi yang dapat dilakukan dalam pengembangan SDM guru adalah dengan mensinergikan continous training and development $(C T D$,$) evaluasi kinerja dan$ membangun semangat integrasi dakwah dan pendidikan.

Dampak Pengembangan Sumber Daya Manusia Berbasis Kompetensi

Pendidikan Islam memiliki visi dakwah dan visi pengembangan keilmuan. Pendidikan Islam merupakan pendidikan yang pendirian dan penyelenggaraannya didorong oleh hasrat dan semangat citacita untuk mengejawantahkan nilai-nilai Islam. Hal itu dapat tercermin dalam nama lembaganya maupun kegiatan-kegiatan yang diselenggarakannya. Islam ditempatkan sebagai sumber nilai yang akan diwujudkan dalam seluruh kegiatan pendidikan. Jenis pendidikan yang memberikan perhatian dan sekaligus menjadikan ajaran Islam sebagai ilmu pengetahuan.

Komitmen keislaman komitmen guru profesional adalah tanggung jawab yang tidak hanya dialamatkan kepada manusia, akan tetapi juga dipertanggung jawabkan dihadapan Allah SWT. Pertanggungjawaban profesi dalam pandangan Islam tidak saja bersifat 
horizontal-formal sesama manusia, tetapi juga bersifat, yakni taggung jawab terhadap Allah SWT. Komitmen yang tinggi sangat diperlukan dalam sebuah organisasi, karena terciptanya komitmen yang tinggi akan mempengaruhi situasi kerja yang profesional. Komitmen organisasi tidak dapat dipisahkan dengan loyalitas. Pemahaman demikian membuat istilah loyalitas dan komitmen mengandung makna yang confuse.

Loyalitas secara sempit diartikan sebagai seberapa lama seorang karyawan bekerja dalam suatu organisasi atau sejauh mana mereka tunduk pada perintah atasan tanpa melihat kualitas kontribusi terhadap organisasi. Muncul suatu fenomena di Indonesia bahwa seorang karyawan akan dinilai loyal, bilamana tunduk pada atasan walaupun bukan dalam konteks hubungan kerja. Komitmen adalah tindakan yang diambil untuk menopang suatu pilihan tindakan tertentu sehingga pilihan tindakan itu dapat dijalankan dengan mantap dan sepenuh hati.

Komitmen guru professional adalah suatu keterikatan diri terhadap tugas dan kewajiban sebagai guru yang dapat melahirkan tanggung jawab dan sikap responsive dan inovatif terhadap pekembangan ilmu pengetahuan dan teknologi. Jadi di dalam komitmen tersebut terdapat beberapa unsur antara lain adanya kemampuan memahami diri dan tugasnya, pancaran sikap batin (kekuatan batin) kekuatan dari luar dan tanggap terhadap perubahan. Unsur-unsur inilah yang melahirkan tanggung jawab terhadap tugas dan kewajiban yang menjadi komitmen seseorang sehingga tugas tersebut dilakukan dengan penuh keikhlasan.

Tanggung jawab keguruan yang lahir dari komitmen guru profesional adalah tanggung jawab yang tidak hanya dialamatkan kepada manusia, akan tetapi juga harus dipertanggungjawabkan di hadapan Allah SWT. Pertanggungjawaban profesi dalam pandangan Islam tidak saja bersifat horizontal formal sesama manusia, tetapi juga bersifat vertikal, yakni tanggung jawab terhadap Allah SWT. Seseorang tidak puas dengan pekerjaan tertentu, dan ketidakpuasan tersebut bila menjalar ke organisasi. Rasa tidak puas dapat mendorong seseorang untuk mempertimbangkan diri minta berhenti.

Komitmen seseorang terhadap organisasi juga didasari pada sikap keikhlasan yang dimiliki seseorang. Komitmen tampak dalam bentuk sikap yang saling berhubungan erat, identifikasi dengan misi organisasi, keterlibatan secara psikologis dengan tujuan-tujuan organisasi, dan loyalitas serta keterikatan dengan organisasi.

Pengembangan sumber daya manusia yang berbasis kompetensi diharapkan SDM (guru) memiliki kompetensi pedagogik, kompetensi profesional, kompetensi sosial dan kompetensi kepribadian juga memiliki soft kompetensi. Komitmen dan keikhlasan ini merupakan soft kompetensi, sebagai penekanan dimensi kompetensi kepribadian. Upaya mewujudkan soft kompetensi diwujudkan melalui kegiatan perencanaan, pembinaan dan motivasi sehingga dihasilkan SDM yang kompeten yang memiliki jiwa komitmen, keikhlasan dan professional. Hal tersebut akhirnya melahirkan guru atau SDM yang memiliki karakter berbasis religious.

Peran manajemen sumber daya manusia meliputi tiga hal, yaitu pengadaan tenaga kerja yang efektif, membangun tenaga kerja yang efektif dan mempertahankan tenaga kerja yang efektif. Ketiga langkah ini merupakan langkah kunci untuk menghasilkan sumber daya manusia (SDM) yang diharapkan. Untuk menghasilkan SDM yang diharapkan harus dimujlai dengan langkah pengadaan SDM, membangun SDM dan dilanjutkan dengan mempertahankan SDM.

\section{Kesimpulan}

Berdasarkan fokus penelitian, paparan data dan temuan penelitian maka dapat disimpulkan sebagai berikut:

1. Perencanaan SDM guru di SD Islam dilakukan dengan menggunakan pendekatan kompetensi berbasis religius. Langkahnya: a) analisis kebutuhan, b) penentuan standar kualifikasi pendidik (akademis, 
religius, pengalaman, motivasi dan dakwah), c) seleksi, dengan open system selection, d) magang dan evaluasi, meliputi: kompetensi, motivasi dan komitmen pengabdian.

2. Strategi pengembangan SDM berbasis kompetensi di SD Islam dengan mensinergikan continous training and development (CTD), evaluasi kinerja dan membangun semangat integrasi dakwah dan pendidikan. Sasaran pengembangan SDM pada aspek: a) komitmen dan pengabdian, melalui; pemberian kompensasi, pengembangan karir, pembinaan pribadi dan keluarga, dan silaturahmi; b) peningkatan kemampuan akademik dan spiritual melalui pelatihan dan sosialisasi, supervisi, studi lanjut, motivasi bekerja adalah ibadah, doa bersama, mendekatkan diri kepada Allah (al qiyadah).

3. Dampak pengembangan SDM guru di SD Islam, guru memiliki motivasi kerja tinggi, mampu menjadi teladan bagi siswa, memiliki loyalitas tinggi dan memiliki komitmen terhadap perhatian dan pelayanan terbaik kepada siswa.

\section{Daftar Pustaka}

Al- Baihaqy, Syu'abul iman, CD maktabah Syamilah, juz 3, tp, tt.

Al-'Adawi, Musthofa. 2009. Anakku! Sudah Tepatkah Pendidikannya? (Terj. Beni Sarbeni dan Izzudin Karimi). Bogor: Pustaka Ibnu Katsir.

Ali Imron "et.all", 2003. Manajemen Pendidikan Analisis Substantif dan Aplikasinya dalam Institusi Pendidikan. Malang: Penerbit Universitas Negeri Malang.

Al-Syaibany, Omar Mohammad Al-Toumi. 1975. Falsafah Pendidikan Islam, Jakarta: Bulan Bintang.

An Nawawi, Imam. 2009. Riyadus Shalihin Edisi Bahasa Indonesia: Menggapai Surga dengan Rahmat Allah. terj. Abdul Rosyad Shiddiq. Jakarta: Akbar Media.

Antonio, Muhammad Syafi'i. 2007. Muhammad SAW the Super Leader
Super Manager. Jakarta: ProLM Center.

Bennis, Warren dan Patricia Ward Biederman. 1997. Organizing Genius: The Secrets of Creative Collaboration. London: Nicholas Brealey Publishing.

Bogdan \& Biklen. 1992. Qualitative Research for Education, an Introduction to Theory and Methods (2nd Edition). Boston: Allyn and Bacon Inc.

Fadjar, A. Malik. 2005. Holistik Pemikiran Pendidikan. Jakarta: PT. Raja Grafindo Persada.

1998. Visi Pembaharuan Pendidikan Islam. Jakarta: LP3NI.

Griffin, Ricky W. dan Ronald J. Eberts. 2002. Bussiness. New Jersey: Prentice Hall.

Hamka. 1982. Tafsir Al Azhar. Jakarta: Pustaka Panjimas.

Hawwa, Said. 2006. Kajian Lengkap Penyucian Jiwa Tazkiyatun Nafs Intisari Ihya Ulumuddin. Jakarta: Pena.

Indayati, Retno. 2008. Psikologi Pendidikan. Tulungagung: CESMID.

Katsir, Al Imam abul Fida Ismail ibnu. 1998. Terjemah Tafsir Ibnu Katsir Juz 27, terj. Bahrun Abu Bakar. Jakarta: Sinar Baru Algesindo.

Kementerian Agama. 2010. Al Quran dan Tafsirnya (edisi yang disempurnakan) Jilid X. Jakarta: Lentera Abadi.

Klett, Fanny. The Design of a Sustainable Competency-Based Human Resources Management: a Holistic Approach, Knowlwdge Management \& E-Learning: An International Journal, Vol 2, No. 3.

Madjid, Nurcholish. 2003. Membangun Indonesia Masa Depan, dalam Ismet Dja'far (eds.), Bangunlah Jiwanya Bangunlah Badannya; Komitmen KAHMI untuk Indonesia Raya. Jakarta: KAHMI.

Mangkuprawiro, Tb. Sjafri. 2004. Manajemen Sumber Daya Manusia Strategik. Jakarta: Ghalia Indonesia.

Metro TV, Managing the Nation with Tanri Abeng, Tanggal 19 Mei 2011. 
Mullins, Laurie J., 2002. Management and organizational Behaviour 6th edition. England: Financial Time.

Mulyasa. 2003. Menjadi Kepala Sekolah Profesional dalam Konteks Mensukseskan MBS dan KBK. Bandung: Remaja Rosdakarya. 2007. Standar Kompetensi dan Sertifikasi Guru. Bandung: Remaja Rosdakarya.

Peraturan Pemerintah Nomor 19 Tahun 2005 Tentang Standar Nasional Pendidikan. Jakarta: Dirjenpendis Depag RI.

Qomar, Mujamil. 2009. Manajemen Pendidikan Islam; Strategi Baru Pengelolaan Lembaga Pendidikan Islam. Jakarta: Erlangga.

Raharjo, Muhamad Muiz. 2011. Manajemen Sumber Daya Manusia yang Unggul, Cerdas, dan Berkarakter Islami. Yogyakarta: Gava Media, 2011.

Ramayulis. 2002. Psikolgi Agama. Jakarta: Kalam Mulia.

Rasiyo. 2005. Berjuang Membangun Pendidikan Bangsa: Pijar-Pijar Pemikiran Dan Tindakan. Malang: Pustaka Kayu Tangan.

Riyanto, Yatim. 2001. Metodologi Penelitian Pendidikan. Surabaya: SIC.

Sinamora, Henry. 2004. Manajemen Sumber Daya Manusia Part One. Malang: STIE YKPN.

Sugiyono, Memahami Penelitian Kualitatif, Bandung: CV. Alfabeta, 2005.

Sukmadinata, Nana Syaodih. 2008. Metode Penelitian Pendidikan. Bandung: Remaja Rosdakarya.

Sumanto, Wasty. 1984. Psikologi Pendidikan. Jakarta: Rajawali Press.

Suprayogo, Imam, Pengantar Rektor, Dalam Mudjia Rahardjo (Ed), Quo Vadis Pendidikan Islam: Pembacaan Realitas Pendidikan Islam, Sosial dan Keagamaan, Malang: UIN Malang Press, 2006. Quo Vadis Madrasah, Gagasan Aksi \& sosuli Pembangunan Madrasah, Yogyakarta: Hikayat Publishing, 2007.

Suwatno, dan Donni Juni Priansa. 2013. Manajemen SDM dalam Organisasi
Publik dan Bisnis. Bandung: Alfabeta.

Syafi'ie, Imam. 1992. Konsep Guru Menurut Al- Ghazali: Pendekatan Filosofis Pedagogis. Yogyakarta: Duta Pustaka.

Thalhah, Imam. 2011. Total Quality Manajemen Pendidikan di Lembaga Pendidikan Islam, Makalah dalam Stadium General PPS STAIN Tulungagung tanggal 17 Februari 2011.

Timpe, A. Dale. 2002. Seri Manajemen Sumber Daya Manusia: Memimpin Manusia, Diterjemahkan oleh Sofyan Cikmat. Jakarta: PT Elex Media Komputindo.

Tobroni. 2008. Pendidikan Islam: Paradigma Teologis, Filosofis dan Spiritual. Malang: UMM Press.

UIN Malang. 2007. Tarbiyah Uli Al-Albab, Dzikir, Fikr dan Amal Shaleh, Konsep Pendidikan. Malang: UIN Malang Press.

Undang-Undang Republik Indonesia Nomor 14 Tahun 2005 tentang Guru dan Dosen, Jakarta: Direktorat Jendral Pendidikan Islam, Depag, RI, 2006.

Undang-Undang Republik Indonesia Nomor 20 Tahun 2003 Tentang SISDIKNAS. Jakarta: Dirjen Pendis, Departemen Agama RI, 2006.

Widjajakusuma, M. Karebet. 2003. Pengantar Manajemen Syariat. Jakarta: Khairul Bayan Press.

Wiratmo, Masykur. 2001. Pengantar Kewiraswastaan: Kerangka Dasar Memasuki Dunia Bisnis. Yogyakarta: BPFE-Yogyakarta.

Yasin, Abu. 2007. Strategi Pendidikan Negara Khilafah. Bogor: Pustaka Thoriqul Izzah.

Yazid, Syamsurizal dkk. 2007. Membangun Kompetensi Insani Mengembangkan Kepemimpinan Madani. Malang: UMM. 